\title{
Decomposing the Education Wage Gap: Everything but the Kitchen Sink
}

\author{
Julie L. Hotchkiss and Menbere Shiferaw
}

\begin{abstract}
The authors use a multitude of data sources to provide a comprehensive, multidimensional decomposition of wages across both time and educational status. Their results confirm the importance of investments in and use of technology, which has been the focus of most of the previous literature. The authors also show that demand and supply factors played very different roles in the growing wage gaps of the 1980s and 1990s.
\end{abstract}

Federal Reserve Bank of St. Louis Review, July/August 2011, 93(4), pp. 243-71.

\section{BACKGROUND}

T here is a clear consensus in the economics literature that the gap in wages between more highly skilled and less-skilled workers has been increasing. Research findings on this topic agree that the gap began to widen considerably in the 1970s (for example, see Piketty and Saez, 2003). Much of the focus on the growing wage gap is motivated by its implications for income inequality. Whether income inequality serves as an engine of economic growth by providing powerful incentives or acts as a hindrance to economic potential, a clear picture of the driving forces behind its growth is essential to inform the debate.

Much of the literature places the blame for the growing skills wage gap on increasing returns to postsecondary education. Ingram and Neumann (2006), however, argue that years of education is a weak measure of skill in the analysis of wage distribution and that much more skill heterogeneity exists among workers. They find that the return to years of education remains constant after con- trolling for skills. However, given the high degree of correlation between education and skill and the fact that education is typically the mechanism through which one achieves a higher skill level, this paper focuses on education-based wage differentials rather than skill differentials and refers to individuals with more education as highly skilled workers and those with less education as lowerskilled workers.

Figure 1 uses data from this article's analysis to show how the wage gaps between education groups have changed from 1970 to 2000 . Guvenen and Kuruscu (2007) find that the overall wage inequality between the college group and the high school group rose only modestly during the 1970s because the between-group inequality was actually falling as within-group inequality was rising. This is consistent with the means plotted in Figure 1; the gap between high school and college and the gap between college and more and less than college (between-group comparisons) fell fairly dramatically, but the gap between high school and less than high school and the gap

\footnotetext{
Julie L. Hotchkiss is a research economist and policy adviser at the Federal Reserve Bank of Atlanta and adjunct professor at Georgia State University. Menbere Shiferaw is a quantitative research analysis specialist at the Federal Reserve Bank of Atlanta. The authors thank Mookie Hojiwala and Anne Flatness at the Bureau of Economic Analysis for assistance with trade data; David Autor, David Dorn, and Christopher Cunningham for assistance with commuting zone questions; and Mark Leonard, participants at the Western Economic Association meetings, and participants at the Federal Reserve System Committee on Applied Microeconomics meetings for comments. Valuable research assistance was provided by Andrew Balthrop, Nicole Baerg, and Fernando Rios-Avila.

(C) 2011, The Federal Reserve Bank of St. Louis. The views expressed in this article are those of the author(s) and do not necessarily reflect the views of the Federal Reserve System, the Board of Governors, or the regional Federal Reserve Banks. Articles may be reprinted, reproduced, published, distributed, displayed, and transmitted in their entirety if copyright notice, author name(s), and full citation are included. Abstracts, synopses, and other derivative works may be made only with prior written permission of the Federal Reserve Bank of St. Louis.
} 


\section{Figure 1}

\section{Education Wage Gap Over Time}

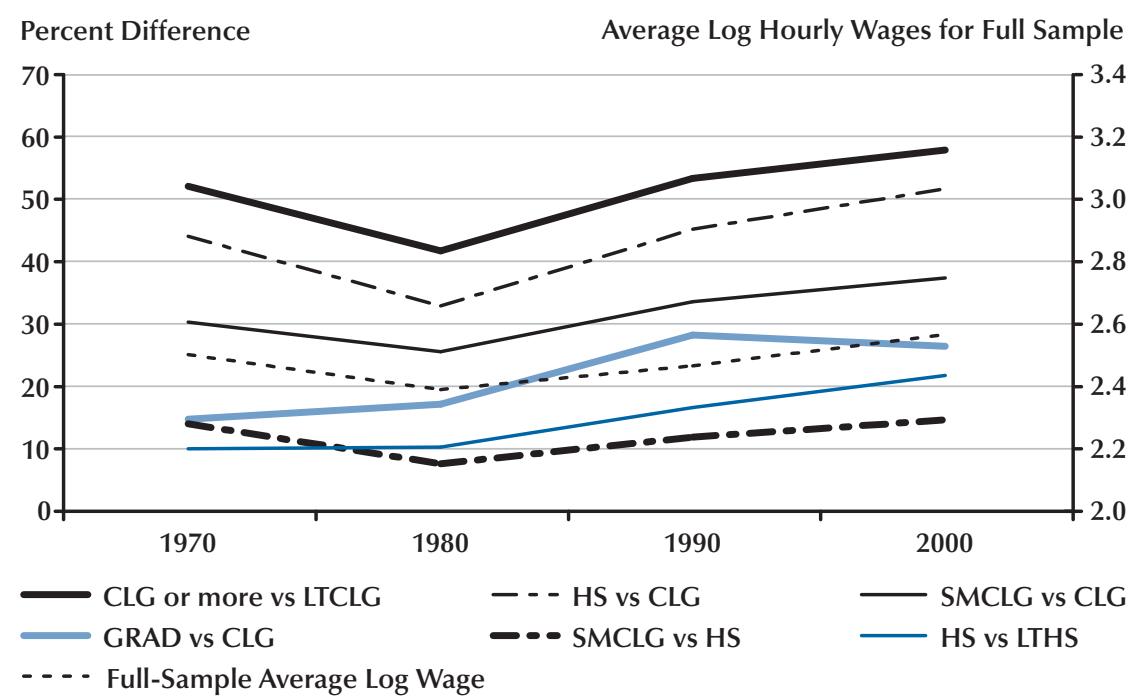

NOTE: LTHS, less than high school; HS, high school; LTCLG, less than college; SMCLG, some college; CLG, college; GRAD, more than college.

between graduate and college (both could be considered more within-group comparisons) have risen. After 1980, however, the wage gaps between all but one pair of education groups grew, with some moderation of that growth since 1990.

If the labor market can be thought of as two sectors-one that employs skilled workers and one that employs less-skilled workers-the literature suggests multiple supply and demand reasons for the earnings gap growth. The most widely hypothesized reason for the increase in the earnings gap is an increase in demand for skilled workers resulting from technological change, or skill-biased technological change. As industries/ firms increase the adoption of computer-based technologies into their production processes in response, for example, to the decline in the price of technology or the abundance of relatively cheap skilled labor, their demand for skilled workers increases. The "skilled worker" in this case includes those who know how to use the technology and those whose productivity is enhanced by computers.
Autor, Katz, and Kearney (2006) find that computerization has not only increased the demand for highly skilled workers (those with abstract thinking-type jobs complemented by computers), but has also decreased the demand for intermediate-skilled workers (those with routine task-type jobs easily replaced by computers). This increase in demand for skilled workerseither ceteris paribus or accompanied by a decline in demand for intermediate-skilled, less-educated workers-will increase the education wage gap.

As the demand for skilled labor increases, the returns to a college education should also increase, which, in turn, should lead to an increase in the supply of educated workers, which should put downward pressure on the skills wage gap. However, the wage gap has continued to increase. Consistent with this observation, Crifo (2008) argues that the increased demand for skill among educated workers results in fewer workers with ordinary skills seeking higher education. The net result is a reduction in the supply of educated workers available to meet the growing demand, 
thus contributing an additional factor that increases the wage gap. ${ }^{1}$

Card and Lemieux (2001) analyze the wage gap between college and high school graduates for younger and older men and find that the education wage gap for older workers has remained relatively stable while the gap among younger workers has risen sharply since the mid-1970s. Their explanation, also consistent with analysis in Topel (1997), is that the relative supply of young collegeeducated workers has slowed, while that of older college-educated workers has remained steady. Thus, because the current demand for college labor is increasing faster than the supply, wage inequality continues to increase. Lemieux (2006) provides additional documentation that increasing returns to postsecondary education account for most of the growth in wage inequality.

Card and DiNardo (2002), among others, are critical of skill-biased technological change as the source of the growing wage gap (especially since 1980). The primary basis for this criticism is that although technology continued to advance dramatically through the 1990s, the growth in skill-based earnings inequality was much slower than in the 1980s. In addition, researchers have identified a number of alternative potential contributors to the growing wage gap. Some examples include (i) declining unionization, as in Card and DiNardo (2002), which would result in lower wages among workers in sectors more likely to be unionized-the less-skilled; (ii) the increased labor force participation of women, as in Topel (1997), which would increase the supply of workers to traditionally lower-paying occupations; (iii) shifts in immigration source countries, as in Topel (1997), which has more recently increased the supply of less-skilled workers from Latin America; and (iv) shifts in product demand, as in Autor, Katz, and Kearney (2006). Piketty and Saez (2003) cite a trend in reporting stock options as wages and changing social norms regarding what is an acceptable "high wage" as contributors to the measured growth in the wage gap. Topel (1997) explores a number of potential supplyside contributors to the wage gap and finds that

1 Goldin and Katz (2008, especially Chap. 3) also share the view that the supply of educated workers has not recently kept up with the demand. the weight of evidence for the growing gap falls on increasing returns to education for explaining the growth in earnings inequality.

Our paper joins this vast literature in an attempt to contribute a better understanding of the relative contributions of different supply and demand factors in explaining the growing earnings inequality between education levels. The contribution of the analysis in this paper includes using a multitude of data sources in an attempt to capture more of the variation across demand and supply factors that affect workers' wages across educational groups. As Kranz (2006) identified, many previous studies focus on either demand or supply factors. While Kranz's (2006) goal was to exhaust both supply and demand factors in the aggregate, comparing changes in the wage gap across countries, our goal is to do so in an analysis at the individual-worker level.

In addition, contributions of the composition of groups of workers and how their characteristics translate into wages are decomposed not only across groups, but also across time in a fairly straightforward way to directly address the question of the relative importance of different contributors to the changing wage gap. The analysis is at an individual level but incorporates local labor market variations through regressors, such as immigration, mobility, and unemployment rates, at the commuting zone (CZ) level. The advantage of using regressors at the $\mathrm{CZ}$ level, as opposed to regressors measured at the metropolitan statistical area or county level, is that this area measure better characterizes the actual labor market in which a worker's wages are determined. For example, in addition to the possibility that immigration status may affect a worker's wage, it is well known that immigrants tend to be geographically concentrated; thus, capturing this labor marketspecific concentration-as well as changes in concentration-might be important in explaining wage differences across education groups.

The analysis herein confirms the previously documented importance of technology in explaining the wage gap growth during the 1980s and 1990s. However, our specification allows us to move beyond this simple conclusion and identify the mechanisms through which technology boosted the wages of both highly skilled and lower-skilled workers. 


\section{METHODOLOGY AND DATA}

The strategy used to examine changes in the education wage gap over time is a straightforward, reduced-form approach that relates numerous supply and demand factors to the measured change in the wage gap between workers with varying levels of educational attainment. The analysis is at the individual level, which allows for a truly marginal analysis of the impact of the change in each of the factors on the observed change in the wage gap between two periods.

\section{Methodology}

The determinants of the measured wage of two education groups (A and B) are estimated in three time periods (1980, 1990, and 2000). The change in the wage gap ( $W G$ ) between the two education groups and between two time periods ( $j$ and $k$ ) can be expressed as

$$
\begin{aligned}
& W G_{A, B}^{k}-W G_{A, B}^{j} \\
& =\left[\ln W_{A}^{k}-\ln W_{B}^{k}\right]-\left[\ln W_{A}^{j}-\ln W_{B}^{j}\right],
\end{aligned}
$$

where log wages of worker with education $i$ in time period $t$ are described as

$$
\ln W_{i}^{t}=\mathrm{X}_{\mathrm{i}}^{\mathrm{t}} \beta^{\mathrm{t}}+\mathrm{Y}_{\mathrm{i}}^{\mathrm{t}} \alpha^{\mathrm{t}}+\mathrm{Z}_{\mathrm{i}}^{\mathrm{t}} \delta^{\mathrm{t}}+\varepsilon_{i}^{t},
$$

where $\mathrm{X}_{\mathrm{i}}^{\mathrm{t}}$ is a vector of demand factors in time $t$ that would be expected to affect the wage of this worker and would typically be measured at the industry, occupation, or CZ level; $\mathrm{Y}_{\mathrm{i}}^{\mathrm{t}}$ is a vector of supply factors (mostly measured at the individual or CZ level); and $\mathrm{Z}_{\mathrm{i}}^{\mathrm{t}}$ is a vector of CZ, institutional, and other characteristics expected to affect the labor market environment in which wages are being determined.

Full descriptions of the regressors and their expected contribution to wage determination are provided in Table A1 (Appendix A). Worker demand regressors include characteristics that describe or are brought to the labor market by employers. Specifically, these include industrylevel investment in computers and computer software, individual-level expected use of computers at work, industry-level value added, and industry and occupation CZ employment shares.
Supply regressors include characteristics that describe or are brought to the labor market by workers. Specifically, these include lagged values of immigrant penetration; demographics such as race, gender, and marital status; human capital measures, which include age and expected home computer use; an indicator for the presence in a CZ of at least one postsecondary institution offering a bachelor's degree; the share of the CZ workforce that is female; and lagged values of CZ population and share of the population with the worker's same level of education.

Institutional characteristics are factors not specifically brought by either employers or workers but which still describe the environment of the labor market. These include the extent of unionization within a worker's industry, the CZ unemployment rate, mobility rate of the population in a worker's CZ, and industry and occupational dummy variables.

The wage gap estimated for each pair of skill groups and years is decomposed as follows:

$$
\begin{aligned}
& W G_{A, B}^{k}-W G_{A, B}^{j} \\
& =\left[\ln W_{A}^{k}-\ln W_{B}^{k}\right]-\left[\ln W_{A}^{j}-\ln W_{B}^{j}\right] \\
(3) & =\left[\mathrm{T}_{A}^{k} \Omega_{A}^{k}-\mathrm{T}_{B}^{k} \Omega_{B}^{k}\right]-\left[\mathrm{T}_{A}^{j} \Omega_{A}^{j}-\mathrm{T}_{B}^{j} \Omega_{B}^{j}\right] \\
& =\Omega_{A}^{k}\left(\mathrm{~T}_{A}^{k}-\mathrm{T}_{A}^{j}\right)+\mathrm{T}_{A}^{j}\left(\Omega_{A}^{k}-\Omega_{A}^{j}\right) \\
& +\left[-\Omega_{B}^{k}\left(\mathrm{~T}_{B}^{k}-\mathrm{T}_{B}^{j}\right)\right]+\left[-\mathrm{T}_{B}^{j}\left(\Omega_{B}^{k}-\Omega_{B}^{j}\right)\right],
\end{aligned}
$$

where $\mathrm{T}=[\mathrm{XYZ}]$ and $\Omega=[\beta \alpha \delta]^{\prime} .^{2}$ This decomposition is structured to determine how much of the wage gap growth between years $j$ and $k$ can be explained by changes in the endowments of skill groups (e.g., use of a computer at home, mobility) and how much can be explained by changes in how the respective labor markets value those endowments (differences in estimated coefficients across time). If a term is estimated to be positive, the difference (in college or high school graduates' characteristics between the two years or in estimated valuation of those characteristics) contributes positively to the growing

\footnotetext{
2 Also see Wellington (1993), who uses this same decomposition to explore changes in the male/female wage gap.
} 
skills wage gap. If a term is estimated to be negative, it reduces the measured skills wage gap.

The decomposition has four terms. The first term, $\Omega_{A}^{k}\left(\mathrm{~T}_{A}^{k}-\mathrm{T}_{A}^{k}\right)$, indicates the contribution to the wage gap growth of changes in endowments of workers in skill group A between years $j$ and $k$. The second term, $\mathrm{T}_{A}^{j}\left(\Omega_{A}^{k}-\Omega_{A}^{j}\right)$, indicates the contribution to the wage gap growth of the change in valuation of endowments of workers in skill group A between years $j$ and $k$. The third term, $\left[-\Omega_{B}^{k}\left(\mathrm{~T}_{B}^{k}-\mathrm{T}_{B}^{j}\right)\right]$, indicates the contribution to the wage gap growth of changes in endowments of workers in skill group B between years $j$ and $k$. And the fourth term, $-\mathrm{T}_{B}^{j}\left(\Omega_{B}^{k}-\Omega_{B}^{j}\right)$, indicates the contribution to the wage gap growth of the change in valuation of endowments of workers in skill group B.

\section{Data}

The data for the wage gap analysis are from several sources. Details and variable descriptions of data sources can be found in Appendix A. Major data sources include the Integrated Public Use Microdata Series, National Income and Product Accounts, Department of Commerce, National Bureau of Economic Analysis, and the Current Population Survey. The main data source is the Integrated Public Use Microdata Series, from which individual-level data on wages, human capital, demographics, and institutional factors were extracted. We include all workers 18 to 64 years of age. In addition to providing the individual-level wage, education, and other demographic characteristics, these data also provide the CZ-level characteristics included in the regression (the construction of CZs is also described in Appendix A). CZ characteristics are constructed using the same sample of 18- to 64-year-olds. CZ-level characteristics are expected to capture the importance of changing local labor market characteristics in determining changes in the skills wage gap. As pointed out by Autor and Dorn (2008), this level of aggregation is preferred to using (i) metropolitan statistical areas, which exclude individuals not located in a metropolitan area, and (ii) counties, which reflect artificial geographic boundaries.
Consistent with most of the literature on skills wage gaps or income inequality, such as Lemieux (2006), we make several decisions regarding topcoded and outlier observations (in hours or earnings). Our outlier restrictions are binding on the top end in that it is highly unlikely that top-coded earnings would have survived our outlier restrictions. We drop all observations with reported hours top-coded at 99 hours per week; this amounts to 0.21 percent of the 1980 sample, 0.38 percent of the 1990 sample, and 0.06 percent of the 2000 sample. In addition, using real 2000 dollars, we drop observations if individuals earned less than $\$ 1$ per hour or more than $\$ 1,000$ per hour. These restrictions result in a loss of 0.55 percent of the 1980 sample, 0.27 percent of the 1990 sample, and 0.14 percent of the 2000 sample.

Regressors are separated into groups based on the mechanism through which they are expected to affect wages. For example, demand for more highly skilled workers is expected to be related to the increase in employer investment in computer hardware and software. If employment in a worker's industry represents a relatively smaller share of overall employment in the worker's local labor market, it is expected that demand for workers, and thus wages, will be lower in that industry. In addition, increases in immigration that bring a competing skill type to a local market are expected to exert downward pressure on the wages of workers of that skill type. Table 1 presents sample means for the regressors used in the analysis, separated by whether the regressor is expected to capture the influences of demand, supply, demographic, or institutional factors on wages; sample distributions across industries and occupations are also provided.

Clearly, the classification of regressors as supply or demand influences is somewhat arbitrary. Generally, we classify factors that come to the labor market through the worker as supply factors and factors that come to the labor market through the employer as demand factors. The number of observations ranges from roughly 1.5 million high school graduates and 375,000 college graduates in 1980 to 1.8 million high school graduates and 922,000 college graduates in 2000 . The characteristics of workers, employers, and 


\section{Table 1}

\section{Sample Means by Year}

\begin{tabular}{|c|c|c|c|}
\hline Regressors & 1980 & 1990 & 2000 \\
\hline \multicolumn{4}{|l|}{ Demand factors } \\
\hline Computer investment ( $\$$ billions) & $\begin{array}{c}0.529 \\
(0.639)\end{array}$ & $\begin{array}{c}1.082 \\
(1.252)\end{array}$ & $\begin{array}{c}2.000 \\
(2.650)\end{array}$ \\
\hline Software investment ( $\$$ billions) & $\begin{array}{c}0.291 \\
(0.320)\end{array}$ & $\begin{array}{c}1.065 \\
(0.994)\end{array}$ & $\begin{array}{c}3.456 \\
(3.399)\end{array}$ \\
\hline Probability of computer use at work & $\begin{array}{c}0.228 \\
(0.138)\end{array}$ & $\begin{array}{c}0.378 \\
(0.180)\end{array}$ & $\begin{array}{c}0.513 \\
(0.206)\end{array}$ \\
\hline Industry value added (\$ trillions) & $\begin{array}{c}0.159 \\
(0.140)\end{array}$ & $\begin{array}{l}(0.207) \\
(0.180)\end{array}$ & $\begin{array}{l}(0.280) \\
(0.231)\end{array}$ \\
\hline Industry employment share & $\begin{array}{c}0.811 \\
(0.056)\end{array}$ & $\begin{array}{c}0.829 \\
(0.047)\end{array}$ & $\begin{array}{c}0.813 \\
(0.049)\end{array}$ \\
\hline Occupation employment share & $\begin{array}{c}0.813 \\
(0.061)\end{array}$ & $\begin{array}{c}0.831 \\
(0.053)\end{array}$ & $\begin{array}{c}0.816 \\
(0.054)\end{array}$ \\
\hline \multicolumn{4}{|l|}{ Supply factors } \\
\hline Probability of computer use at home & $\begin{array}{c}0.523 \\
(0.166)\end{array}$ & $\begin{array}{c}0.566 \\
(0.147)\end{array}$ & $\begin{array}{c}0.809 \\
(0.096)\end{array}$ \\
\hline Female share of CZ labor force & $\begin{array}{c}0.427 \\
(0.019)\end{array}$ & $\begin{array}{c}0.454 \\
(0.015)\end{array}$ & $\begin{array}{c}0.466 \\
(0.013)\end{array}$ \\
\hline Share of CZ with less than high school diploma & $\begin{array}{c}0.261 \\
(0.067)\end{array}$ & $\begin{array}{c}0.163 \\
(0.054)\end{array}$ & $\begin{array}{c}0.133 \\
(0.047)\end{array}$ \\
\hline Share of CZ with high school diploma & $\begin{array}{c}0.391 \\
(0.052)\end{array}$ & $\begin{array}{c}0.349 \\
(0.060)\end{array}$ & $\begin{array}{c}0.323 \\
(0.061)\end{array}$ \\
\hline Share of CZ with college degree & $\begin{array}{c}0.089 \\
(0.020)\end{array}$ & $\begin{array}{c}0.135 \\
(0.038)\end{array}$ & $\begin{array}{c}0.157 \\
(0.043)\end{array}$ \\
\hline Share of CZ with postgraduate degree & $\begin{array}{c}0.073 \\
(0.024)\end{array}$ & $\begin{array}{c}0.067 \\
(0.024)\end{array}$ & $\begin{array}{c}0.081 \\
(0.030)\end{array}$ \\
\hline Share of CZ born in North America (excluded) & $\begin{array}{c}0.921 \\
(0.077)\end{array}$ & $\begin{array}{c}0.897 \\
(0.107)\end{array}$ & $\begin{array}{c}0.857 \\
(0.127)\end{array}$ \\
\hline Share of CZ born in Latin America or Caribbean & $\begin{array}{c}0.027 \\
(0.043)\end{array}$ & $\begin{array}{c}0.043 \\
(0.066)\end{array}$ & $\begin{array}{c}0.071 \\
(0.080)\end{array}$ \\
\hline Share of CZ born in Europe or Asia & $\begin{array}{c}0.040 \\
(0.031)\end{array}$ & $\begin{array}{c}0.047 \\
(0.040)\end{array}$ & $\begin{array}{c}0.061 \\
(0.052)\end{array}$ \\
\hline Share of CZ born in other non-North American countries & $\begin{array}{c}0.013 \\
(0.016)\end{array}$ & $\begin{array}{c}0.013 \\
(0.016)\end{array}$ & $\begin{array}{c}0.011 \\
(0.012)\end{array}$ \\
\hline University or college in $\mathrm{CZ}=1$ & $\begin{array}{c}0.982 \\
(0.133)\end{array}$ & $\begin{array}{c}0.968 \\
(0.177)\end{array}$ & $\begin{array}{c}0.961 \\
(0.193)\end{array}$ \\
\hline \multicolumn{4}{|l|}{ Demographics } \\
\hline Age (years) & $\begin{array}{c}36.22 \\
(12.85)\end{array}$ & $\begin{array}{c}37.58 \\
(11.94)\end{array}$ & $\begin{array}{c}39.27 \\
(12.17)\end{array}$ \\
\hline Female $=1$ & $\begin{array}{c}0.446 \\
(0.497)\end{array}$ & $\begin{array}{c}0.459 \\
(0.498)\end{array}$ & $\begin{array}{c}0.491 \\
(0.500)\end{array}$ \\
\hline
\end{tabular}

NOTE: Standard errors are listed in parentheses. The white race category may include respondents of Hispanic ethnicity. 


\section{Table 1, cont'd}

\section{Sample Means by Year}

\section{Regressors}

Demographics, cont'd

White $($ excluded $)=1$

Black $=1$

Asian $=1$

Other race $=1$

Married with spouse present $=1$

\section{Institutional factors}

CZ unemployment rate

Percent of workers covered by union in industry

Mobility rate of $\mathrm{CZ}$ population

\section{Industries}

Natural resources and $\operatorname{mining}=1$

Construction $=1$

Manufacturing $=1$

Transportation and utilities $=1$

Wholesale trade $=1$

Retail trade $=1$

Financial activities $=1$

Information $=1$

Professional and business services $=1$

Education and health services $=1$

Leisure and hospitality $=1$

Other services $($ excluded $)=1$
1980

0.873

(0.333)

0.101

(0.301)

0.018

(0.135)

0.008

(0.091)

0.622

(0.485)

0.061

(0.020)

0.201

(0.148)

0.120

(0.060)

0.030

(0.171)

0.066

(0.248)

0.259

(0.438)

0.058

(0.233)

0.048

(0.214)

0.169

(0.375)

0.047

(0.212)

0.019

(0.138)

0.062

(0.241)

0.176

(0.381)

0.023

(0.150)

0.043

(0.202)
1990

$\begin{array}{cc}0.879 & 0.783 \\ (0.326) & (0.412) \\ 0.087 & 0.097 \\ (0.281) & (0.296) \\ 0.026 & 0.038 \\ (0.159) & (0.190) \\ 0.008 & 0.082 \\ (0.090) & (0.274) \\ 0.613 & 0.576 \\ (0.487) & (0.494)\end{array}$

0.059

(0.016)

0.050

(0.015)

0.119

(0.119)

0.124

(0.051)

(0.054)

0.025

(0.156)

0.076

(0.265)

0.158

(0.365)

0.055

(0.228)

0.037

(0.188)

0.123

(0.328)

0.067

(0.251)

0.030

(0.170)

0.094

(0.291)

0.207

(0.405)

0.083

(0.276)

0.045

(0.208)

NOTE: Standard errors are listed in parentheses. The white race category may include respondents of Hispanic ethnicity. 
Table 1, cont'd

\section{Sample Means by Year}

\begin{tabular}{|c|c|c|c|}
\hline Regressors & 1980 & 1990 & 2000 \\
\hline \multicolumn{4}{|l|}{ Occupations } \\
\hline Managerial and professional specialty (excluded) $=1$ & $\begin{array}{c}0.216 \\
(0.412)\end{array}$ & $\begin{array}{c}0.253 \\
(0.435)\end{array}$ & $\begin{array}{c}0.264 \\
(0.441)\end{array}$ \\
\hline Technical sales and administrative support = 1 & $\begin{array}{c}0.300 \\
(0.458)\end{array}$ & $\begin{array}{c}0.322 \\
(0.467)\end{array}$ & $\begin{array}{c}0.302 \\
(0.459)\end{array}$ \\
\hline Service $=1$ & $\begin{array}{c}0.114 \\
(0.318)\end{array}$ & $\begin{array}{c}0.079 \\
(0.270)\end{array}$ & $\begin{array}{c}0.137 \\
(0.344)\end{array}$ \\
\hline Farming, forestry, and fishing $=1$ & $\begin{array}{c}0.017 \\
(0.128)\end{array}$ & $\begin{array}{c}0.023 \\
(0.151)\end{array}$ & $\begin{array}{c}0.028 \\
(0.165)\end{array}$ \\
\hline Precision production, craft, and repair $=1$ & $\begin{array}{c}0.135 \\
(0.342)\end{array}$ & $\begin{array}{c}0.129 \\
(0.335)\end{array}$ & $\begin{array}{c}0.117 \\
(0.321)\end{array}$ \\
\hline Operators, fabricators, and laborers $=1$ & $\begin{array}{c}0.217 \\
(0.412)\end{array}$ & $\begin{array}{c}0.194 \\
(0.395)\end{array}$ & $\begin{array}{c}0.153 \\
(0.360)\end{array}$ \\
\hline \multicolumn{4}{|l|}{ Wage and education variables } \\
\hline Hourly wage & $\begin{array}{c}14.113 \\
(17.937)\end{array}$ & $\begin{array}{c}15.47 \\
(20.266)\end{array}$ & $\begin{array}{c}17.86 \\
(26.443)\end{array}$ \\
\hline Less than high school $=1$ & $\begin{array}{c}0.228 \\
(0.419)\end{array}$ & $\begin{array}{c}0.134 \\
(0.340)\end{array}$ & $\begin{array}{c}0.121 \\
(0.326)\end{array}$ \\
\hline High school = 1 & $\begin{array}{c}0.393 \\
(0.489)\end{array}$ & $\begin{array}{c}0.348 \\
(0.476)\end{array}$ & $\begin{array}{c}0.328 \\
(0.470)\end{array}$ \\
\hline College $=1$ & $\begin{array}{c}0.098 \\
(0.297)\end{array}$ & $\begin{array}{c}0.148 \\
(0.355)\end{array}$ & $\begin{array}{c}0.158 \\
(0.365)\end{array}$ \\
\hline Postgraduate $=1$ & $\begin{array}{l}0.084 \\
(0.277)\end{array}$ & $\begin{array}{c}0.079 \\
(0.269)\end{array}$ & $\begin{array}{l}0.084 \\
(0.277)\end{array}$ \\
\hline
\end{tabular}

NOTE: Standard errors are listed in parentheses. The white race category may include respondents of Hispanic ethnicity.

CZs have changed over time as might be expected. For example, the amount of money invested by firms in computer hardware and software has increased almost 4 times and 12 times, respectively, between 1980 and 1990 and between 1990 and 2000, while the probability of workers using computers at work has more than doubled over both time periods. In addition, computer use at home has increased by 56 percent $^{3}$; education levels overall have increased; the share of the CZ born in Latin America has increased more than the share born in other parts of the world; the population has aged; marriage and unionization

3 The probability of computer use at home seems high at 52 percent. Note that the Current Population Survey supplement from 1984 is used as a proxy for computer use in 1980. rates have declined; and the shares of workers employed in financial activities, information, leisure and hospitality, and professional and business services occupations have all increased, as expected.

Recent investigations of the growth in real wages find the greatest growth in the upper portion of the earnings distribution. ${ }^{4}$ Only Lemieux (2006) makes a direct link between the upper portion of the earnings distribution and the highest levels of education. Figures 2 and 3 plot normalized hourly wages by worker percentiles and education levels, respectively, to compare the data

\footnotetext{
4 For example, see Guvenen and Kuruscu (2007), Lemieux (2006), Ginther and Rassier (2006), Autor, Katz, and Kearney (2006), Piketty and Saez (2003), and Topel (1997).
} 


\section{Figure 2}

\section{Indexed Hourly Wages Across Worker Percentiles}

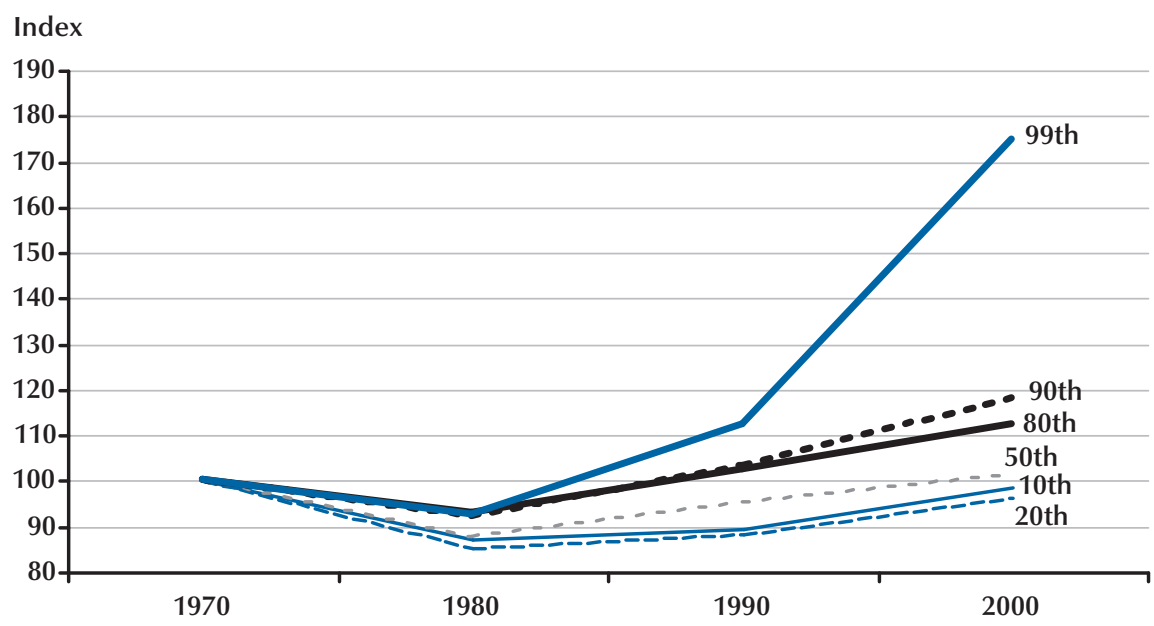

NOTE: Hourly wages are indexed to the value of hourly wages in 1970.

\section{Figure 3}

\section{Indexed Hourly Wages Across Education Levels}

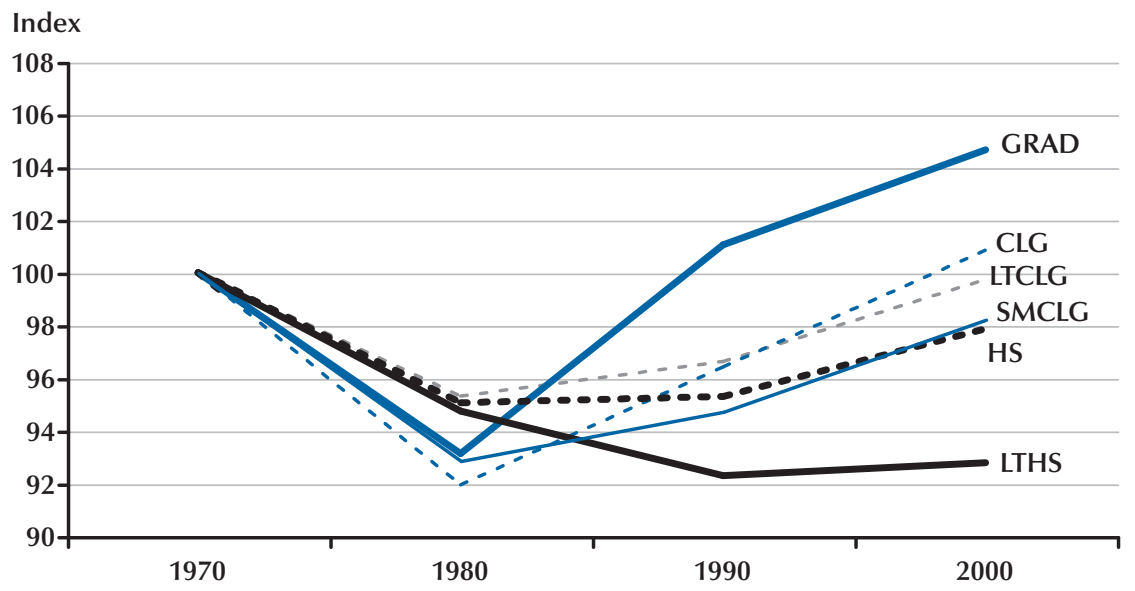

NOTE: Hourly wages are indexed to the value of hourly wages in 1970. LTHS, less than high school; HS, high school; LTCLG, less than college; SMCLG, some college; CLG, college; GRAD, more than college. 
Figure 4

\section{Relative Contributions of Changes in Endowments and Valuation of Endowments to the Changing Wage Gap Between High School and College Graduates}

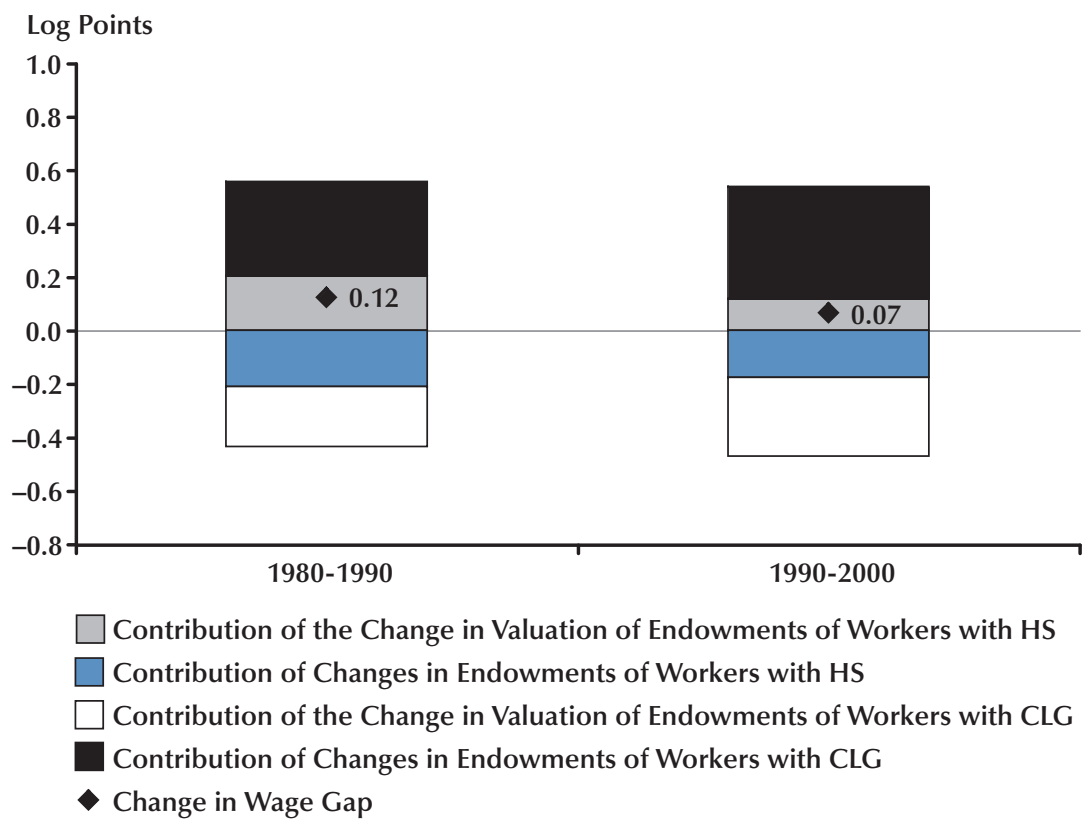

NOTE: CLG, college; HS, high school.

used in this analysis with those in previous analyses. Figure 2 confirms that the most dramatic growth in wages between 1980 and 2000 (especially between 1990 and 2000) occurred in the upper portion of the wage distribution-among workers in the 99th percentile. Figure 3 illustrates how this growth across the wage distribution translates into growth across education levels. While the growth among workers with a postgraduate degree outpaced growth for workers of lower education levels, the wage gap between the highest and next-highest education level (postgraduate versus college) shrank slightly, while the gap between college graduates and high school graduates continued to grow through 2000.

\section{RESULTS}

Tables 2 and 3 show the decompositions of changes in the wage gap between college and high school graduates from 1980 to 1990 (Table 2) and from 1990 to 2000 (Table 3). Figures 4 and 5 reproduce these results graphically to more easily visualize the relative contributions of changes in endowments of each educational group, contributions of changes in how those endowments translate into wages, and how different groups of regressors (e.g., supply vs. demand) compare with each other. Appendix B contains the estimated parameter coefficients for each year and each education level.

\section{Relative Contributions of Changes in Endowments and Coefficients}

Considering the endowments of workers with different education levels and how those endowments translate into wages, the relative contributions are fairly consistent across the two decades (see Figure 4). Changes in college graduates' endowments and the labor-market valuation of 


\section{Figure 5}

\section{Relative Contributions of Changes in Supply and Demand (and Other) Factors to the Changing Wage Gap Between High School and College Graduates}

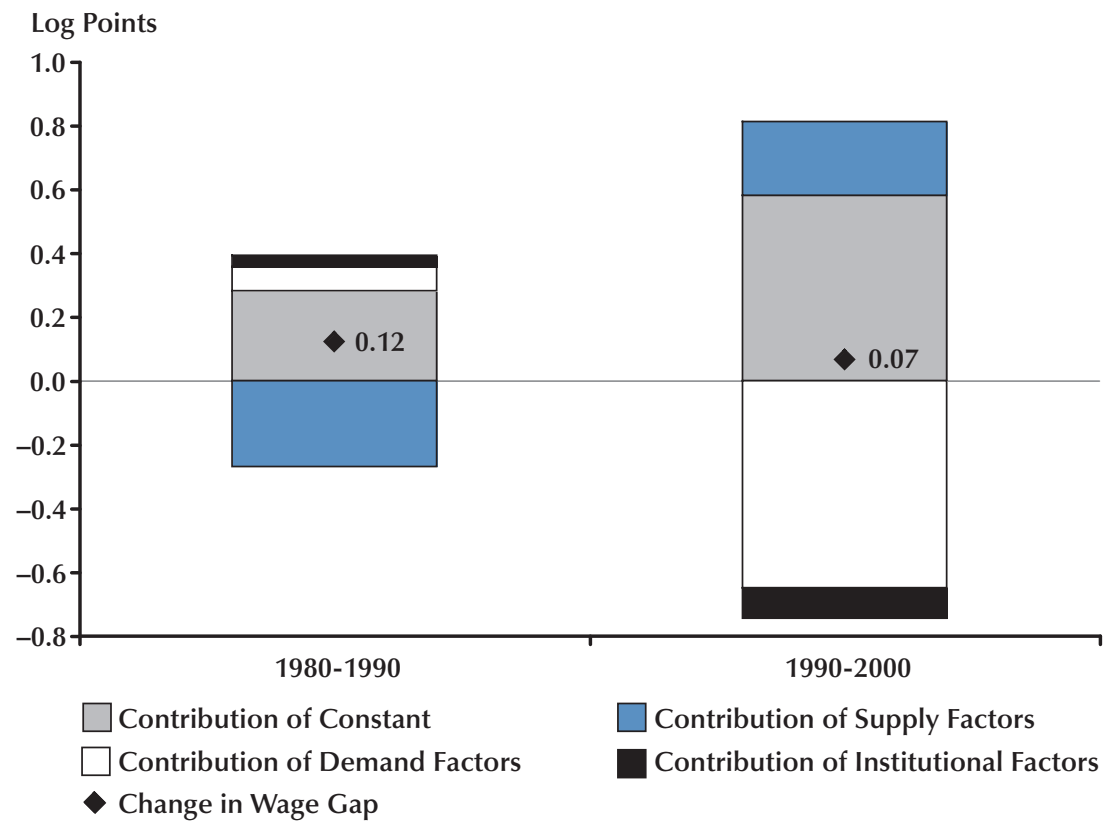

high school graduates' endowments (the coefficient effect) worked to increase the wage gap during both decades. However, changes in high school graduates' endowments and the changes in the labor-market valuation of college graduates' endowments exerted downward pressure on the wage gap in both decades. The implication is that, overall, both high school and college graduates were increasing their wage-enhancing characteristics (both individual and job-related) during both decades. The increasing endowments among college graduates, however, exceeded those experienced by high school graduates. As discussed in the next section, technology investments and increased computer use were the driving forces behind this greater endowment effect for college graduates.

The declining value of those characteristics (the coefficient effect) also exerted opposing pressures on the wage gap. The decline in valuation was greater among college graduates, particularly in the 1990s, which helps to explain the slowdown in the growth of the wage gap during that decade. As discussed in more detail in the next section, the driving force behind this large negative coefficient effect in the 1990s among college graduates was the significant decline in labor market return to occupational employment share.

\section{Relative Contributions of Demand, Supply, and Institutional Factors}

Figure 5 graphically illustrates the relative contributions of demand and supply factors to the changing wage gap between high school and college graduates across the 1980s and 1990s. There are some striking differences. But first we note that the significant contribution of unexplained factors in the determination of the wage gap across both decades is apparent through the size of the contribution of the constant term. An important potential component of the constant term is the change over time in the relative ability 


\section{Table 2}

\section{Decomposition of the Change in the Wage Gap Between College and High School Graduates (1980-1990)}

\begin{tabular}{|c|c|c|c|c|c|}
\hline \multirow[b]{2}{*}{$\begin{array}{l}\text { Components } \\
\text { of decomposition }\end{array}$} & \multicolumn{2}{|c|}{ College graduates } & \multicolumn{2}{|c|}{ High school graduates } & \multirow[b]{2}{*}{$\begin{array}{c}\text { Total } \\
\text { (row sum) }\end{array}$} \\
\hline & $\begin{array}{l}\text { Contribution } \\
\text { of changes in } \\
\text { endowments }\end{array}$ & $\begin{array}{l}\text { Contribution } \\
\text { of changes in } \\
\text { coefficients }\end{array}$ & $\begin{array}{l}\text { Contribution } \\
\text { of changes in } \\
\text { endowments }\end{array}$ & $\begin{array}{l}\text { Contribution } \\
\text { of changes in } \\
\text { coefficients }\end{array}$ & \\
\hline Total (column sum) & $\begin{array}{l}\text { 0.3528 }^{* * *} \\
(\mathbf{0 . 0 0 4 1 )}\end{array}$ & $\begin{array}{l}-0.2241^{* * *} \\
(\mathbf{0 . 0 0 4 4 )}\end{array}$ & $\begin{array}{l}-\mathbf{0 . 2 1 0 8}^{* * *} \\
(\mathbf{0 . 0 0 2 0})\end{array}$ & $\begin{array}{l}0.2049 * * * \\
(0.0022)\end{array}$ & $\begin{array}{l}0.1229 * * * \\
(0.0067)\end{array}$ \\
\hline Demand factors & $\begin{array}{l}\text { 0.2614*** } \\
(0.0041)\end{array}$ & $\begin{array}{c}-0.0274 \\
(0.0630)\end{array}$ & $\begin{array}{l}-0.1479 * * * \\
(0.0015)\end{array}$ & $\begin{array}{c}-0.0103 \\
(0.0255)\end{array}$ & $\begin{array}{c}0.0759 \\
(0.0681)\end{array}$ \\
\hline $\begin{array}{l}\text { Technology demand (industry } \\
\text { hardware and software investment, } \\
\text { probability of worker using } \\
\text { computer at work) }\end{array}$ & $\begin{array}{l}0.2171^{* * *} \\
(0.0039)\end{array}$ & $\begin{array}{l}0.1323^{* * *} \\
(0.0161)\end{array}$ & $\begin{array}{l}-0.1192^{* * *} \\
(0.0014)\end{array}$ & $\begin{array}{l}0.0184^{* * *} \\
(0.0045)\end{array}$ & $\begin{array}{l}0.2486^{* * *} \\
(0.0173)\end{array}$ \\
\hline $\begin{array}{l}\text { Industry demand (industry value } \\
\text { added, CZ employment share in } \\
\text { worker's industry) }\end{array}$ & $\begin{array}{l}0.0423 * * * \\
(0.0008)\end{array}$ & $\begin{array}{l}0.1234^{* * *} \\
(0.0436)\end{array}$ & $\begin{array}{l}-0.0279 * * * \\
(0.0004)\end{array}$ & $\begin{array}{c}-0.0766^{* * *} \\
(0.0196)\end{array}$ & $\begin{array}{c}0.0612 \\
(0.0478)\end{array}$ \\
\hline $\begin{array}{l}\text { Occupation demand (CZ employment } \\
\text { share in worker's occupation) }\end{array}$ & $\begin{array}{l}0.0020^{* * *} \\
(0.0006)\end{array}$ & $\begin{array}{l}-0.2831^{* * *} \\
(0.0625)\end{array}$ & $\begin{array}{l}-0.0007^{* *} \\
(0.0003)\end{array}$ & $\begin{array}{c}0.0479 * \\
(0.0253)\end{array}$ & $\begin{array}{l}-0.2340^{* * *} \\
(0.0674)\end{array}$ \\
\hline Supply factors & $\begin{array}{l}0.1005^{* * *} \\
(0.0025)\end{array}$ & $\begin{array}{l}0.2114 * * * \\
(0.0493)\end{array}$ & $\begin{array}{l}-0.0767 * * * \\
(0.0013)\end{array}$ & $\begin{array}{l}-0.5043^{* * *} \\
(0.0242)\end{array}$ & $\begin{array}{l}-0.2692^{* * *} \\
(\mathbf{0 . 0 5 5 0 )}\end{array}$ \\
\hline $\begin{array}{l}\text { Low-skilled immigrant supply } \\
\text { (percent of CZ population born in } \\
\text { Central America, Caribbean, or } \\
\text { South America) }\end{array}$ & $\begin{array}{l}-0.0054^{* * *} \\
(0.0004)\end{array}$ & $\begin{array}{c}-0.0005 \\
(0.0010)\end{array}$ & $\begin{array}{l}0.0067^{* * *} \\
(0.0002)\end{array}$ & $\begin{array}{l}-0.0047^{* * *} \\
(0.0004)\end{array}$ & $\begin{array}{l}-0.0040^{* * *} \\
(0.0012)\end{array}$ \\
\hline $\begin{array}{l}\text { Highly skilled immigrant supply } \\
\text { (percent of CZ population born in } \\
\text { non-Latin American countries) }\end{array}$ & $\begin{array}{l}0.0128^{* * *} \\
(0.0003)\end{array}$ & $\begin{array}{l}0.0534^{* * *} \\
(0.0025)\end{array}$ & $\begin{array}{l}0.0006^{* * *} \\
(0.0002)\end{array}$ & $\begin{array}{l}-0.0644^{* * *} \\
(0.0013)\end{array}$ & $\begin{array}{c}0.0024 \\
(0.0029)\end{array}$ \\
\hline $\begin{array}{l}\text { Technology supply (probability } \\
\text { of worker using computer at home) }\end{array}$ & $\begin{array}{l}0.0120^{* * *} \\
(0.0008)\end{array}$ & $\begin{array}{l}-0.0405^{* * *} \\
(0.0143)\end{array}$ & $\begin{array}{l}-0.0001^{* * *} \\
(0.0000)\end{array}$ & $\begin{array}{l}0.0568^{* * *} \\
(0.0045)\end{array}$ & $\begin{array}{l}0.0282^{* *} \\
(0.0150)\end{array}$ \\
\hline $\begin{array}{l}\text { Other supply (percent of CZ } \\
\text { population of worker's skill group, } \\
\text { lagged a decade; CZ population, } \\
\text { lagged a decade; college or university } \\
\text { in CZ; percent of CZ labor force that } \\
\text { is female) }\end{array}$ & $\begin{array}{l}0.0572^{* * *} \\
(0.0021)\end{array}$ & $\begin{array}{l}0.4465^{* * *} \\
(0.0397)\end{array}$ & $\begin{array}{l}-0.0409^{* * *} \\
(0.0012)\end{array}$ & $\begin{array}{l}-0.4448^{* * *} \\
(0.0217)\end{array}$ & $\begin{array}{c}0.0179 \\
(0.0453)\end{array}$ \\
\hline $\begin{array}{l}\text { Demographics (age, gender, race, } \\
\text { ethnicity, marital status) }\end{array}$ & $\begin{array}{l}0.0239^{* * *} \\
(0.0007)\end{array}$ & $\begin{array}{l}-0.2476^{* * *} \\
(0.0202)\end{array}$ & $\begin{array}{l}-0.0429 * * * \\
(0.0003)\end{array}$ & $\begin{array}{l}-0.0472^{* * *} \\
(0.0092)\end{array}$ & $\begin{array}{l}-0.3137^{* * *} \\
(0.0222)\end{array}$ \\
\hline $\begin{array}{l}\text { Institutional factors } \\
\mathrm{CZ} \text { unemployment rate, industry } \\
\text { extent of unionization, mobility rate } \\
\text { of population in CZ, worker's industry, } \\
\text { and occupation dummy variables }\end{array}$ & $\begin{array}{l}-0.0091^{* * *} \\
(\mathbf{0 . 0 0 0 6 )}\end{array}$ & $\begin{array}{l}-\mathbf{0 . 1 2 8 3} * * * \\
(\mathbf{0 . 0 1 1 8 )}\end{array}$ & $\begin{array}{l}\mathbf{0 . 0 1 3 8} 8^{* * *} \\
(\mathbf{0 . 0 0 0 3 )}\end{array}$ & $\begin{array}{c}0.1586^{*} \\
(0.0072)\end{array}$ & $\begin{array}{l}\text { 0.0350** } \\
(\mathbf{0 . 0 1 3 8 )}\end{array}$ \\
\hline Constant & 0.0000 & $\begin{array}{l}-0.2798 * * * \\
(0.0755)\end{array}$ & 0.0000 & $\begin{array}{l}0.5610 * * * \\
(\mathbf{0 . 0 3 5 5 )}\end{array}$ & $\begin{array}{l}0.2811^{* * *} \\
(\mathbf{0 . 0 8 3 5 )}\end{array}$ \\
\hline
\end{tabular}

NOTE: Standard deviations are listed in parentheses; these have been estimated using the delta method accounting for the sampling variation in the regressors; see Phillips and Park (1988), Oehlert (1992), and Jann (2008). ${ }^{* * *},{ }^{* *}$, and $*$ indicate significance at the 99 , 95, and 90 percent confidence levels, respectively. 


\section{Table 3}

\section{Decomposition of the Change in the Wage Gap Between College and High School Graduates (1990-2000)}

\begin{tabular}{|c|c|c|c|c|c|}
\hline \multirow[b]{2}{*}{$\begin{array}{l}\text { Components } \\
\text { of decomposition }\end{array}$} & \multicolumn{2}{|c|}{ College graduates } & \multicolumn{2}{|c|}{ High school graduates } & \multirow[b]{2}{*}{$\begin{array}{c}\text { Total } \\
\text { (row sum) }\end{array}$} \\
\hline & $\begin{array}{l}\text { Contribution } \\
\text { of changes in } \\
\text { endowments }\end{array}$ & $\begin{array}{l}\text { Contribution } \\
\text { of changes in } \\
\text { coefficients }\end{array}$ & $\begin{array}{l}\text { Contribution } \\
\text { of changes in } \\
\text { endowments }\end{array}$ & $\begin{array}{l}\text { Contribution } \\
\text { of changes in } \\
\text { coefficients }\end{array}$ & \\
\hline Total (column sum) & $\begin{array}{l}0.4195^{* * *} \\
(\mathbf{0 . 0 0 8 2})\end{array}$ & $\begin{array}{l}-0.2960 * * * \\
(0.0084)\end{array}$ & $\begin{array}{l}-0.1755^{* * *} \\
(0.0040)\end{array}$ & $\begin{array}{l}0.1181^{* * *} \\
(0.0043)\end{array}$ & $\begin{array}{l}\text { 0.0661*** } \\
(\mathbf{0 . 0 1 3 1})\end{array}$ \\
\hline Demand factors & $\begin{array}{l}0.2191 * * * \\
(0.0049)\end{array}$ & $\begin{array}{c}-0.6962 \\
(0.0606)\end{array}$ & $\begin{array}{l}-0.0469 * * * \\
(0.0017)\end{array}$ & $\begin{array}{l}-0.1261^{* * *} \\
(0.0266)\end{array}$ & $\begin{array}{l}-0.6502 * * * \\
(0.0663)\end{array}$ \\
\hline $\begin{array}{l}\text { Technology demand (industry } \\
\text { hardware and software investment, } \\
\text { probability of worker using } \\
\text { computer at work) }\end{array}$ & $\begin{array}{l}0.2184^{* * *} \\
(0.0049)\end{array}$ & $\begin{array}{c}0.0397^{*} \\
(0.0208)\end{array}$ & $\begin{array}{l}-0.0613^{* * *} \\
(0.0016)\end{array}$ & $\begin{array}{l}0.1526^{* * *} \\
(0.0060)\end{array}$ & $\begin{array}{l}0.3493^{* * *} \\
(0.0223)\end{array}$ \\
\hline $\begin{array}{l}\text { Industry demand (industry value } \\
\text { added, CZ employment share in } \\
\text { worker's industry) }\end{array}$ & $\begin{array}{l}-0.0073^{* * *} \\
(0.0007)\end{array}$ & $\begin{array}{l}-0.1502^{* * *} \\
(0.0403)\end{array}$ & $\begin{array}{l}0.0065^{* * *} \\
(0.0004)\end{array}$ & $\begin{array}{l}0.1140^{* * *} \\
(0.0204)\end{array}$ & $\begin{array}{c}-0.0370 \\
(0.0451)\end{array}$ \\
\hline $\begin{array}{l}\text { Occupation demand (CZ employment } \\
\text { share in worker's occupation) }\end{array}$ & $\begin{array}{l}0.0080^{* * *} \\
(0.0008)\end{array}$ & $\begin{array}{l}-0.5857^{* * *} \\
(0.0593)\end{array}$ & $\begin{array}{l}0.0079 * * * \\
(0.0004)\end{array}$ & $\begin{array}{l}-0.3927^{* * *} \\
(0.0270)\end{array}$ & $\begin{array}{l}-0.9626^{* * *} \\
(0.0652)\end{array}$ \\
\hline Supply factors & $\begin{array}{l}0.2227 * * * \\
(0.0079)\end{array}$ & $\begin{array}{c}-0.0533 \\
(0.0592)\end{array}$ & $\begin{array}{l}-0.1717^{* * *} \\
(0.0041)\end{array}$ & $\begin{array}{l}0.2334^{* * *} \\
(0.0294)\end{array}$ & $\begin{array}{l}0.2310 * * * \\
(0.0667)\end{array}$ \\
\hline $\begin{array}{l}\text { Low-skilled immigrant supply } \\
\text { (percent of CZ population born in } \\
\text { Central America, Caribbean, or } \\
\text { South America) }\end{array}$ & $\begin{array}{l}-0.0033^{* * *} \\
(0.0003)\end{array}$ & $\begin{array}{l}0.0049^{* * *} \\
(0.0009)\end{array}$ & $\begin{array}{l}0.0072^{* * *} \\
(0.0002)\end{array}$ & $\begin{array}{l}-0.0027^{* * *} \\
(0.0005)\end{array}$ & $\begin{array}{l}0.0608^{* * *} \\
(0.0011)\end{array}$ \\
\hline $\begin{array}{l}\text { Highly skilled immigrant supply } \\
\text { (percent of CZ population born in } \\
\text { non-Latin American countries) }\end{array}$ & $\begin{array}{l}0.0182^{* * *} \\
(0.0004)\end{array}$ & $\begin{array}{l}-0.0106^{* * *} \\
(0.0021)\end{array}$ & $\begin{array}{l}-0.0157^{* * *} \\
(0.0002)\end{array}$ & $\begin{array}{l}0.0332^{* * *} \\
(0.0011)\end{array}$ & $\begin{array}{l}0.0251^{* * *} \\
(0.0024)\end{array}$ \\
\hline $\begin{array}{l}\text { Technology supply (probability of } \\
\text { worker using computer at home) }\end{array}$ & $\begin{array}{l}0.1118^{* * *} \\
(0.0073)\end{array}$ & $\begin{array}{l}0.3045^{* * *} \\
(0.0327)\end{array}$ & $\begin{array}{l}-0.1240^{* * *} \\
(0.0039)\end{array}$ & $\begin{array}{l}-0.1485^{* * *} \\
(0.0074)\end{array}$ & $\begin{array}{l}0.1438^{* * *} \\
(0.0346)\end{array}$ \\
\hline $\begin{array}{l}\text { Other supply (percent of CZ } \\
\text { population of worker's skill group, } \\
\text { lagged a decade; CZ population, } \\
\text { lagged a decade; college or university } \\
\text { in CZ; percent of CZ labor force that } \\
\text { is female) }\end{array}$ & $\begin{array}{l}0.0776^{* * *} \\
(0.0018)\end{array}$ & $\begin{array}{l}-0.3672^{* * *} \\
(0.0411)\end{array}$ & $\begin{array}{l}-0.0281^{* * *} \\
(0.0008)\end{array}$ & $\begin{array}{l}0.3534^{* * *} \\
(0.0258)\end{array}$ & $\begin{array}{c}0.0357 \\
(0.0486)\end{array}$ \\
\hline $\begin{array}{l}\text { Demographics (age, gender, race, } \\
\text { ethnicity, marital status) }\end{array}$ & $\begin{array}{l}0.0184^{* * *} \\
(0.0006)\end{array}$ & $\begin{array}{c}0.0151 \\
(0.0187)\end{array}$ & $\begin{array}{l}-0.0111^{* * *} \\
(0.0003)\end{array}$ & $\begin{array}{l}-0.0019 \\
(0.0105)\end{array}$ & $\begin{array}{c}0.0204 \\
(0.0215)\end{array}$ \\
\hline $\begin{array}{l}\text { Institutional factors } \\
\text { CZ unemployment rate, industry } \\
\text { extent of unionization, mobility rate } \\
\text { of population in CZ, worker's industry, } \\
\text { and occupation dummy variables }\end{array}$ & $\begin{array}{l}-\mathbf{0 . 0 2 2 3} * * * \\
(\mathbf{0 . 0 0 0 8 )}\end{array}$ & $\begin{array}{c}-0.0201 * \\
(0.0107)\end{array}$ & $\begin{array}{l}\mathbf{0 . 0 4 3 2 * * *} \\
(\mathbf{0 . 0 0 0 5 )}\end{array}$ & $\begin{array}{l}-0.0960 * * * \\
(0.0073)\end{array}$ & $\begin{array}{l}-0.0952 * * * \\
(0.0130)\end{array}$ \\
\hline Constant & 0.0000 & $\begin{array}{l}0.4736 * * * \\
(0.0798)\end{array}$ & 0.0000 & $\begin{array}{l}0.1068 * * * \\
(0.0397)\end{array}$ & $\begin{array}{l}\text { 0.5804*** } \\
(\mathbf{0 . 0 8 9 1 )}\end{array}$ \\
\hline
\end{tabular}

NOTE: Standard deviations are listed in parentheses; these have been estimated using the delta method (Phillips and Park, 1988), accounting for the sampling variation in the regressors (see Jann, 2008). ${ }^{* *},{ }^{* *}$, and ${ }^{*}$ indicate significance at the 99,95 , and 90 percent confidence levels, respectively. 
of college and high school graduates. Hendricks and Schoellman (2011) present evidence that a fair amount of the growth in the college wage premium can be attributed to the growth in the relative ability (or "quality") of college graduates compared with high school graduates. Such a change in quality is unmeasured and will, thus, be captured only by the constant term.

Of arguably greater interest here than the role of unmeasurables, however, is that changes in supply, demand, and institutional factors have had completely opposite effects on the wage gap across the two decades. During the 1980s, demand and institutional factors increased the wage gap, while supply factors, as a whole, exerted downward pressure on the wage gap. The opposite was true for the 1990s-supply factors increased the wage gap, while demand and institutional factors decreased it. The most dramatic reversal was among demand factors. Tables 2 and 3 provide details of the relative contributions.

Demand Factors. Consistent with the skillbiased technological change literature, the largest single contributor to the wage-gap-enhancing change in college graduates' endowments was the investment by their employers in technology and their use of computers at work, both in the 1980s and the 1990s. ${ }^{5}$ At the same time, employers of high school graduates were investing in technology and those workers were also increasingly likely to use computers at work, but these changes were not nearly large enough to offset the growth along this dimension among college graduates, particularly in the 1990s. During the 1990s, however, the change in the use of computers at home (a supply factor) by high school graduates was the single largest contributing endowment factor exerting downward pressure on the wage gap $(-0.1240)$. And this downward pressure slightly exceeded the upward pressure of the growing use of home computers by college graduates (0.1118). Perhaps this reflects that increased computer use allowed high school grad-

5 As in Autor, Levy, and Murnane (2003), we measure employers' investments in technology as the total spent on all computer and peripheral equipment and software. Even if new devices were introduced between the 1980s and 1990s, this aggregated measure should be reflective of the total investment. uates to catch up in terms of computer-specific human capital, especially since home computer use by high school graduates was essentially non-existent in the 1980s.

Nonetheless, as in Krueger (1993), we find that computer use at work is rewarded more than computer use at home. For college graduates, a 10-percentage-point increase in the probability of using a computer at work translated into a 3 percent, 7 percent, and 9 percent increase in wages in 1980, 1990, and 2000, respectively (see estimation results in Appendix B). Analogous rewards were 5 percent, 6 percent, and 3 percent for high school graduates. This growing valuation of computer use at work by employers of college graduates (along with the returns workers experience from their employer's technology investments) and the declining (but still positive) valuation of computer use by employers of high school graduates explain why the coefficient effect for technology demand factors is positive for both high school and college graduates in both decades. It also illustrates what others have found: It was not only the increased use of technology among college graduates that translated into faster wage growth, but also the greater translation of technology investment and use into higher wages for college graduates that expanded the wage gap.

The boost to the wage gap from increased technology use and investment between 1980 and $1990(0.2486)$ was almost completely offset by downward pressure imposed by changing occupational demand (-0.2340). Between 1990 and 2000, this downward pressure of changing occupational demand is three times larger than the continued upward pressure on the wage gap imposed by changing technology investment and use. This accounts for the bulk of the flip between the 1980s and 1990s in the direction of the contribution of demand factors. As in Autor, Katz, and Kearney (2006), we measure occupational demand as the share of employment accounted for by each occupation; the greater the share of employment in a particular occupation, the greater the demand for workers with those occupational skills. Generally, the empirical results presented here are consistent with the theoretical conclu- 
sions drawn by Autor, Katz, and Kearney (2006) that market forces likely played an important role in the determination of the wage gap, especially during the 1990s. The downward pressure on the wage gap as a result of changing occupational demand between 1990 and 2000 came from the reduced rewards to employment in occupations dominated by college graduates (even more so than during the 1980s) and the increased rewards to employment in occupations dominated by high school graduates. While the share of jobs populated by high school and college graduates did not substantially change between 1990 and 2000, the labor market rewards of employment in those occupations did. Specifically, a 1-percentagepoint increase in the CZ share of employment in a worker's occupation increased wages among high school graduates by 0.05 percent in 1990 but by 0.53 percent in 2000 (see Appendix B)—thus the relatively large negative coefficient effect in the "Occupation demand" category in Table 3 $(-0.3927)$. At the same time, the analogous coefficient among college graduates decreased from 0.17 to -0.51 , putting further downward pressure on the wage gap (-0.5857).

Autor, Levy, and Murnane (2003) conclude that technological change caused relative demand shifts favoring educated labor (also see Katz and Murphy, 1992). The results from the analysis here suggest that the rewards to that shift in demand toward educated labor were primarily flowing to college graduates through the increased use of and investment by employers in technology. This is consistent with Autor, Levy, and Murnane's (2003) conclusions that technological change caused, rather than reflected, the demand shift toward educated labor (as seen here in both the 1980s and 1990s results).

In addition, the growing rewards to high school graduates through increasing occupational share in the 1990s (as opposed to primarily through technological change) are consistent with Autor, Katz, and Kearney's (2006) evidence of a polarization of the labor market in the 1990s; the marginal productivity of manual task input (supplied by less-educated workers) is complementary with a rise in routine task input (supplied primarily by lower-cost computer capital). There is very little evidence here of this effect in the 1980s, which is, again, consistent with Autor, Katz, and Kearney's (2006) monotonic shift in occupational demand during that decade.

The relatively innocuous impact of the changing industrial employment share is consistent with the findings of Wheeler (2005) and Katz and Murphy (1992) that rising inequality within industries is more important than rising inequality between industries in explaining the growing education gap in both decades.

Supply Factors. During the 1980s, supply factors, as a whole, put downward pressure on the wage gap. The most significant supply factor driving the growing education wage gap during the 1980s was the valuation of demographics $(-0.3137)$, most notably the valuation of demographics of college graduates $(-0.2476)$, the largest contributor to which was age. Between 1980 and 1990, the oldest of the baby boomers were entering their 40s, with the youngest baby boomers graduating from college and entering their $20 \mathrm{~s}$. In addition, increasing numbers of workers with a college degree were entering the workforce (although at a decreasing rate; see Card and Lemieux, 2001). The net result, it appears, was that earlier college-educated boomers were facing significant competition as the youngest of their cohort began graduating from college, putting downward pressure on college wages-thus, the wage gap.

The largest supply factor contributing to the wage gap change during the 1990s was computer use at home (0.1438). Even though high school graduates increased their computer use slightly more than college graduates during this decade, the increased use gave a much larger boost to college graduates' wages (a 0.3045 contribution to the wage gap change) than to high school graduates' wages (a-0.1485 contribution to the wage gap change), making for a net positive contribution to the wage gap. This may be because high school graduates were increasingly less likely to apply their newly acquired computer skills on the job. This accounts for the bulk of the flip between the 1980s and 1990s in the direction of the contribution of supply factors. 
Another significant supply factor change is the share of workers with the same education level (lagged) in the individual's CZ. ${ }^{6}$ Changes in this factor were relatively unimportant in the 1980s but contributed a relatively significant share to wage gap growth in the 1990s. Changes in both the endowment and coefficient effects related to this factor contributed to its sizable contribution. First, college-educated workers became more geographically concentrated and high school graduates became less geographically concentrated (endowment changes). Second, being located in a CZ with a large share of workers with the same skill level was increasingly a bonus for college graduates but became a penalty for high school graduates-a continuation of the decline in return to this characteristic that was also seen between 1980 and 1990. This result is consistent with the finding of others, such as Giannetti (2001) and Hotchkiss, Pitts, and Robertson (2008), that once a workforce has a large enough concentration of highly skilled workers, the workers themselves benefit from the rents generated by skill complementarities. This finding also suggests that the supply effects found at an aggregate level by Card and Lemieux (2001) (fewer available collegeeducated workers boosts their wages) do not necessarily trickle down to the individual level; an individual college graduate captures rents from locating in a labor market with others of the same education level, ceteris paribus.

While Topel (1997) found that the percent of the labor force that is female did not have much impact on growing wage inequality, decomposing that supply factor into endowment and coefficient effects highlights a notable shift from the 1980s to the 1990s. Between 1980 and 1990, the coefficients on the share of the workforce that is female changed from negative (more females in the labor force put downward pressure on wages) to positive. This had the effect of raising both college and high school graduate average wages (making the college graduate coefficient effect for this regressor positive and the high school graduate coefficient effect negative).

6 Details that follow relating to the categories of "Other supply" and "Institutional factors" are not reported individually in Tables 2 and 3 but can be easily constructed using the means in Table 1 and the parameter estimates in Appendix B.
In contrast, between 1990 and 2000, the coefficients on the percentage of the CZ labor force that is female declined for both college and high school graduates, making the impact of the change just the opposite of what occurred during the previous decade. Much has been made of highly educated women "opting out" of the labor force during the 1990s (for example, see Hotchkiss, Pitts, and Walker, 2010). If this took the form of women working fewer hours or in jobs requiring less skill, this opt-out phenomenon could be contributing to the dramatic downward pressure on the wage gap from the percent of the CZ labor force that is female.

Topel (1997) also found that immigration was not particularly important for explaining growing wage inequality during the 1980s. We also found this to be the case for both the 1980s and the 1990s, likely because of the small fraction of the workforce made up by immigrants.

Institutional Factors. Changes in factors that we categorize as institutional increased the wage gap between 1980 and 1990 but decreased the wage gap during the 1990s. Institutional factors are those characteristics that describe the labor market and differ from the characteristics brought to the labor market by employers and workers. Card and DiNardo (2002) point to declining unionization as a major contributor to the growing wage gap between education groups. However, in addition to being a relatively minor contributor in this analysis, controlling for other wage-determining factors at the individual level results in the contribution of unionization (both the change in unionization rates and the change in return to unionization) exerting downward pressure on the wage gap during both decades, although the impact of that downward pressure was much smaller in the 1990s.

Changes in mobility worked in favor of high school graduate wages in the 1990s but had little impact on the changing wage gap in the 1980s. In 1990, there appears to have been a wage penalty for working in a CZ with high levels of mobility for both college and high school graduates, although the penalty was greater among college graduates. In 2000, that penalty became larger for college graduates but became a bonus for high 
school graduates-hence the fairly significant downward pressure on the wage gap. It was also in 2000 that the return to being employed in an occupation with a high employment share increased significantly for high school graduates. The increasing return to mobility may reflect a degree of flexibility among high school graduates that allowed them to take advantage of increased demand for the occupations in which they are employed.

One might also expect to find lower average wages in CZs with an abundance of slack labor. The positive coefficient on the unemployment rate, however, is consistent with the presence of sticky wages (for an example, see Gottschalk, 2005). For any given equilibrium level of wages (characterized by all of the other regressors included in the estimation), the higher the unemployment rate, the higher the observed wage in that labor market is likely to be (the higher the observed wage is above the equilibrium wage). This is not an estimated causal relationship between unemployment and the wage level, but rather, merely a cross-sectional correlation holding all other labor market characteristics constant. The result does not invalidate the frequently replicated negative relationship between wage growth and the unemployment rate (for example, as seen in Aaronson and Sullivan, 2001).

\section{SENSITIVITY ANALYSIS}

One of the main points of the analysis in this paper is that focusing on just one potential contributor to the change in the education wage gap over time runs the risk of biasing the conclusions. This section illustrates just how sensitive the decomposition is to exclusions of various regressors. Three alternative specifications are estimated: (i) excluding the industry and occupation dummy variables, (ii) excluding the technology demand variables, and (iii) excluding all CZ-level regressors. The resulting changes in the decompositions across specifications are illustrated (along with the baseline decompositions) in Figures 6 and 7.

With only one exception, none of the different specifications altered the relative contributions of changes in endowments and coefficients
(Figure 6). Although the individual terms in the decomposition differed in size from the base specification, the relative contributions reflected in the baseline decomposition remained unchanged. The exception was the relative contributions of endowments and coefficients to the observed change in the wage gap between 1990 and 2000 when CZ-level variables are excluded from the analysis; the overwhelming source of the difference in this case is the increase in the unexplained portion of the valuation of endowments among college graduates-as reflected in the estimate of the intercept term. Removing technology demand from the estimation considerably decreased the changes in the contribution of endowments of both college graduates and high school graduates in both decades. The most dramatic effect was the reduction of the change in the valuation of endowments of college graduates during the 1980s.

Removing the industry and occupation dummy variables primarily affected the contribution of the industry and occupation CZ employment shares. This change in contribution manifested itself through an increase in the relative contribution of the CZ occupation employment share to a growing wage gap. This, in turn, reduced the growing advantage of high school graduates over college graduates in demand for their occupational fields. This pattern of change was the same across both decades (see in Figure 6 how the gray section of the second bar in both panels is smaller than the gray section of the first bar). The implication is that excluding occupation and industry fixed effects would have resulted in underestimating the complementary role that demand for high school graduates' skills (as measured by demand for occupational shares of high school graduates) played as the demand for technological skills increased.

The motivation for removing the technology demand factors was to determine which other factors would take the place of this dominant influence on the change in the wage gap. The primary effect of removing technology demand factors was an increase in the relative contribution of supply factors to the growing wage gap. This occurred primarily through an increased 
Figure 6

Sensitivity Analysis: Contributions of Changes in Endowments and Coefficients Across Different Specifications

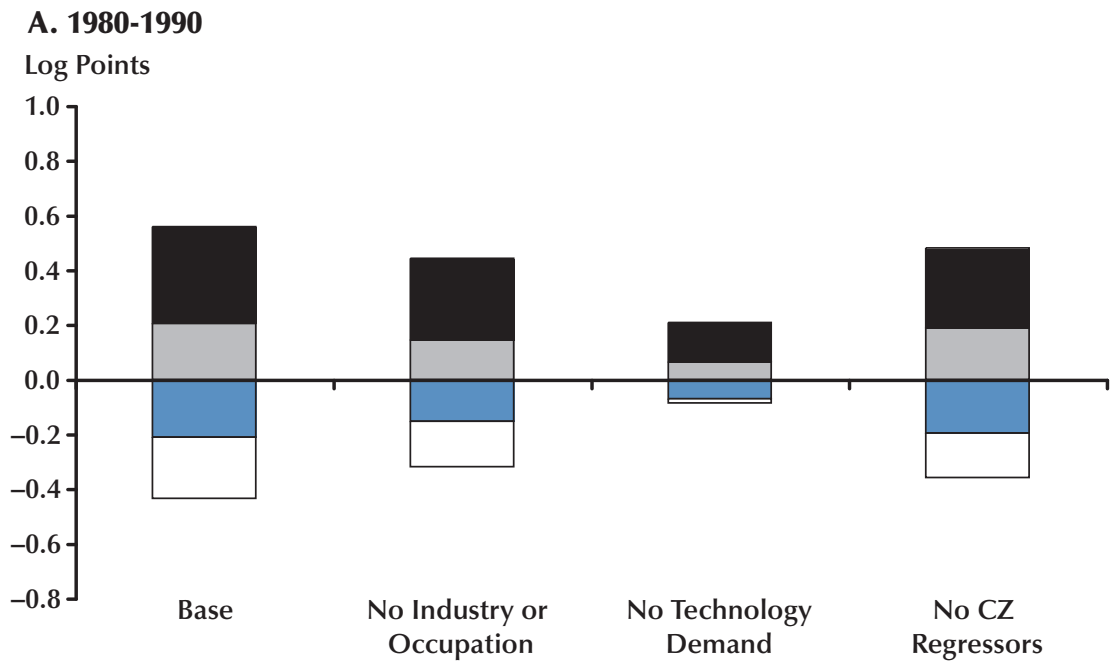

\section{B. 1990-2000}

Log Points
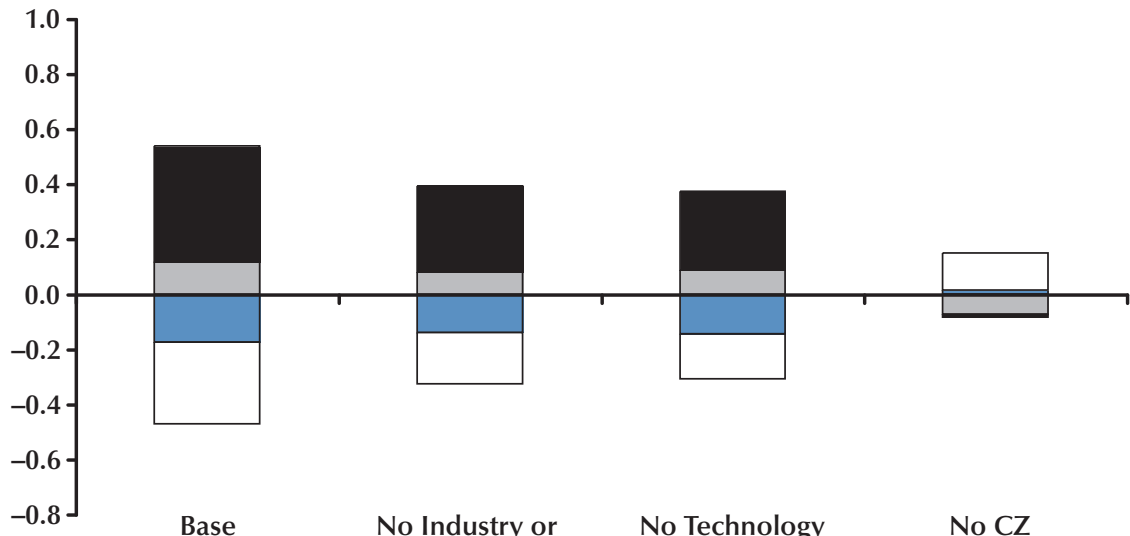

Base

No Industry or

No Technology

No CZ

Occupation

Demand

Regressors

Contribution of the Change in Valuation of Endowments of Workers with HS

Contribution of Changes in Endowments of Workers with HS

$\square$ Contribution of the Change in Valuation of Endowments of Workers with CLG

Contribution of Changes in Endowments of Workers with CLG 
Figure 7

Sensitivity Analysis: Contributions of Changes in Demand, Supply, and Institutional Factors Across Different Specifications

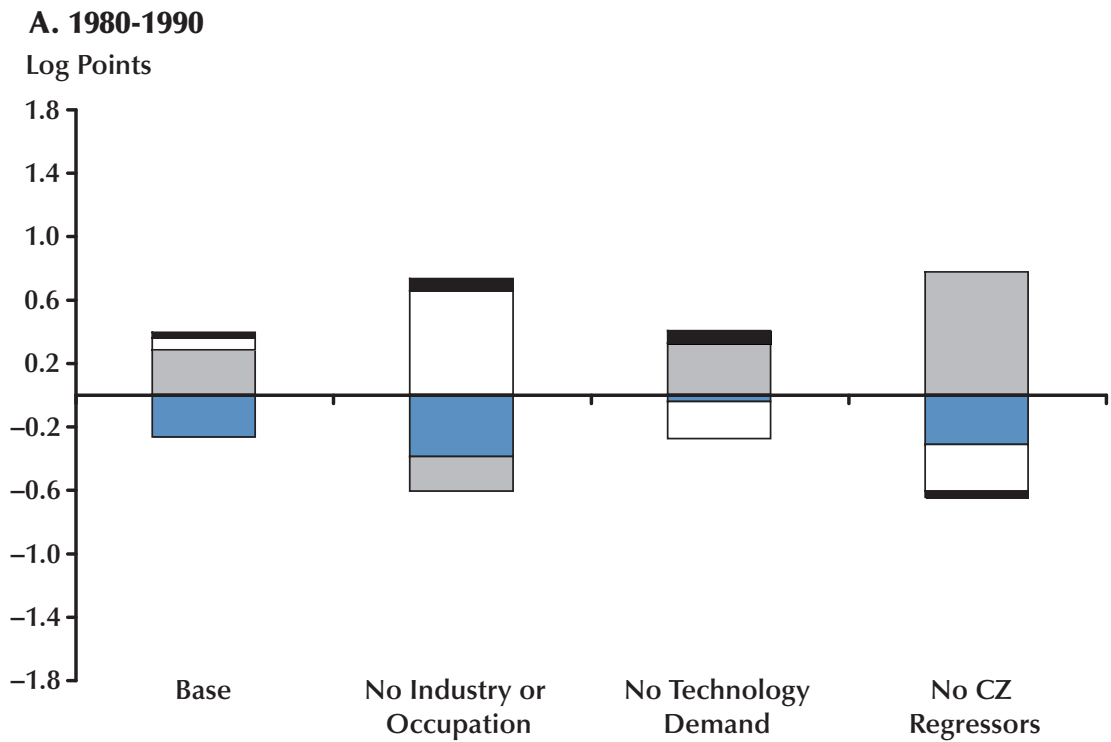

\section{B. 1990-2000}

Log Points

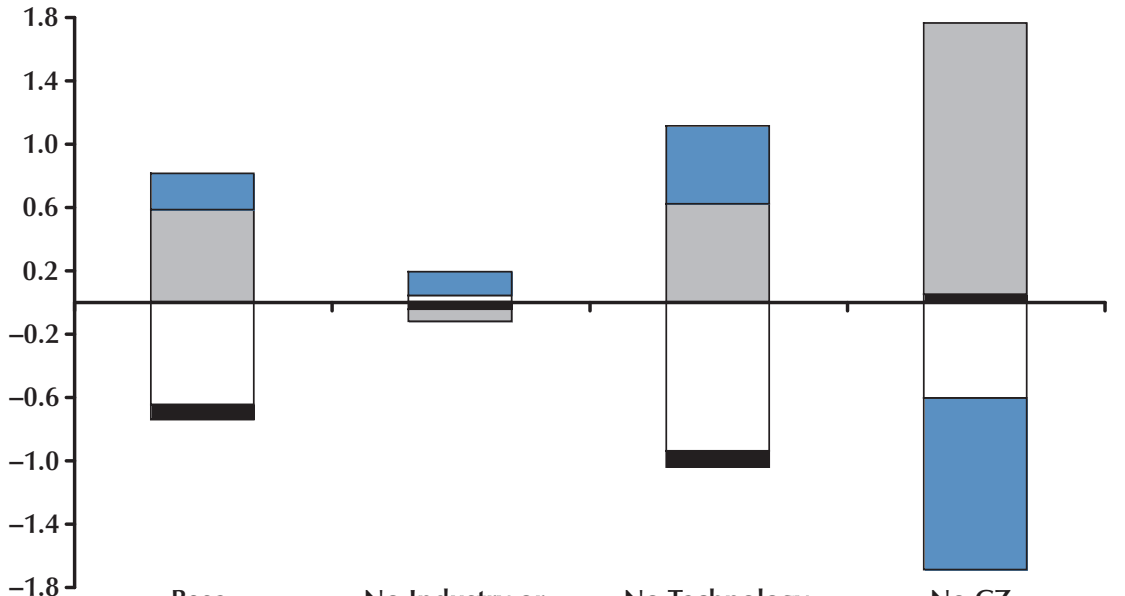

$-1.8$

Base

No Industry or

Occupation

No Technology

No $\mathrm{CZ}$ Demand

Regressors

Contribution of Constant

Contribution of Demand Factors

Contribution of Supply Factors

Contribution of Institutional Factors

NOTE: CZ, commuting zone. 
contribution of technology supply (see how the blue section of the third bar of both panels in Figure 7 compares with the blue section of the first bar; it is a smaller negative contribution in panel $\mathrm{A}$ and a larger positive contribution in panel B).

Excluding CZ-level regressors had a differential effect in the 1980s and 1990s. In the absence of CZ regressors in the 1980s, the contribution of demand factors to the wage gap increase (the white section of the fourth bar in panel A of Figure 7) was reduced significantly, compared with the baseline, primarily through the reduced importance of industry and occupation employment shares. In the 1990s, the contribution of supply factors to the wage gap increase (the blue section of the fourth bar in panel B of Figure 7) was significantly reduced, compared with the baseline, mainly through the reduced importance of home computer use. The increase in the contribution of the intercept was largest in this specification across both decades.

For the most part, with the exception of excluding CZ-level regressors, the relative contributions of changes in endowments and coefficients remain the same across different specifications. However, the relative contributions of supply and demand factors do change in fairly significant ways. Of course, those changes are partially dependent on the categorization of regressors into supply and demand influences, but once there is agreement on that point, it is clearly important to include as many measures as possible of potential influence. It is particularly important to include measures of geographic differences across education groups and time when trying to identify primary contributors to the changing wage gap. ${ }^{7}$

\section{CONCLUSIONS AND IMPLICATIONS}

The analysis in this paper provides a thorough reduced-form investigation of the relative contri-

\footnotetext{
7 Others have documented the importance of geography on wage differences and wage growth. For example, see Bartik (1991), DuMond, Hirsch, and Macpherson (1999), Hirsch (2005), Easton (2006), Hirsch, König, and Möller (2009), and Black, Kolesnikova, and Taylor (2009).
}

butions of supply and demand factors to the growing wage gap between high school and college graduates during the 1980s and the 1990s. Most importantly, the analysis identifies the mechanism through which technological change boosted wages of both groups of workers in each decade. Specifically, in both decades wage gains from increased demand for college graduates flowed through their increased use of technology (and technological investments by their employers), rather than from merely an increase in demand for educated workers. However, the main rewards from technology to high school graduates flowed through increased demand for their particular skills (which are theorized to be complementary to technological advancements), rather than through the use of technology itself. These results provide empirical evidence in support of the theoretical arguments of Autor, Katz, and Kearney (2006) that the labor market of the 1990s experienced a polarization; the marginal productivity of manual-task input (supplied by less-educated workers) is complemented by a rise in routinetask input (supplied primarily by lower-cost computer capital).

In general, the results are mostly consistent with those in the previous literature; however, the individual-level analysis in this paper provides an advantage over some aggregate analyses. For example, whereas Card and Lemieux (2001) found that reduced aggregate supply boosted wages of college graduates, the results here indicate that the marginal effect of a growing concentration of college graduates (increased supply in a geographic area) had an increasingly positive impact on college wages over the two decades, consistent with evidence of rents generated by skill complementarities, as found by Giannetti (2001).

The analysis also demonstrated that supply and demand wage-determining factors had opposite effects in the growth of the wage gap during the 1980s and 1990s; however, changes in endowments of workers with college degrees were largely responsible for the increasing wage gap in both decades. Consistent with the skill-biased technological change literature, technological changethe increased investments in technology and 
computer use by workers (both college and high school graduates)—was the single largest contributing endowment change that affected the wage gap across both decades, even after controlling for as many other demand, supply, and institutional factors as possible.

In addition to contributing to our overall understanding of the dynamics of the wage gap between workers of different education levels during the 1980s and 1990s and the roles that supply and demand factors in each decade played in determining the wage gap, the analysis in this paper provides an even more general lesson. Focusing on only one factor in a complicated market process runs the risk of losing perspective of that factor's relative importance in the determination process or missing the impact of that factor's interaction with other market forces. The sensitivity analysis demonstrated the importance of including as many measures of potential influence as possible when trying to identify sources in the changing wage gap, particularly measures of geographic differences across education groups.

\section{REFERENCES}

Aaronson, Daniel and Sullivan, Daniel G. "Cross-State Evidence on the Relationship Between Unemployment and Wage Growth." Chicago Fed Letter, May 2001, No. 165; www.chicagofed.org/digital assets/publications/chicago fed letter/2001/cflmay2001 165.pdf.

Autor, David and Dorn, David. "Inequality and Specialization: The Growth of Low-Skill Service Jobs in the United States." Unpublished manuscript, Department of Economics, Massachusetts Institute of Technology, July 20, 2008; www.carloalberto.org/files/autor-dorn-specialization-services-july21-2008.pdf.

Autor, David H.; Katz, Lawrence F. and Kearney, Melissa S. “The Polarization of the U.S. Labor Market.” NBER Working Paper No. 11986, National Bureau of Economic Research, January 2006; www.nber.org/papers/w11986.pdf.

Autor, David H.; Levy, Frank and Murnane, Richard J. “The Skill Content of Recent Technological Change: An Empirical Exploration.” Quarterly Journal of Economics, November 2003, 118(4), pp. 1279-333.

Bartik, Timothy J. Who Benefits from State and Local Economic Development Policies? Kalamazoo, MI: W.E. Upjohn Institute for Employment Research, 1991.

Black, Dan A.; Kolesnikova, Natalia A. and Taylor, Lowell. "Earnings Functions When Wages and Prices Vary by Location.” Journal of Labor Economics, 2009, 27(1), pp. 21-47.

Card, Daniel E. and DiNardo, John E. "Skill-Biased Technological Change and Rising Wage Inequality: Some Problems and Puzzles.” Journal of Labor Economics, October 2002, 20(4), pp. 733-83.

Card, Daniel E. and Lemieux, Thomas. "Can Falling Supply Explain the Rising Return to College for Younger Men? A Cohort-Based Analysis.” Quarterly Journal of Economics, May 2001, 116(2), pp. 705-46.

Crifo, Patricia. “Skill Supply and Biased Technical Change.” Labour Economics, October 2008, 15(5), pp. 812-30.

DuMond, J. Michael; Hirsch, Barry T. and Macpherson, David A. "Wage Differentials Across Labor Markets and Workers: Does Cost of Living Matter?” Economic Inquiry, October 1999, 37(4), pp. 577-98.

Easton, Todd. “Metropolitan Wage Levels of Less-Educated Workers: 1986-1999.” Industrial Relations, April 2006, 45(2), pp. 119-46. 


\section{Hotchkiss and Shiferaw}

Giannetti, Mariassunta. “Skill Complementarities and Migration Decisions.” Labour, 2001, 15(1), pp. 1-31.

Ginther, Donna K. and Rassier, Dylan G. "Work Activities as Unmeasured Skills: Do Work Activities Explain Earnings Inequality?” Presented at the Society of Labor Economists Eleventh Annual Meeting, May 2006.

Goldin, Claudia D. and Katz, Lawrence F. The Race Between Education and Technology. Cambridge, MA: Harvard University Press, 2008.

Gottschalk, Peter. "Downward Nominal Wage Flexibility: Real or Measurement Error?" Review of Economics and Statistics, November 2005, 87(3), pp. 556-68.

Guvenen, Fatih and Kuruscu, Burhanettin. "A Quantitative Analysis of the Evolution of the U.S. Wage Distribution: 1970-2000.” NBER Working Paper No. 13095, National Bureau of Economic Research, May 2007; www.nber.org/papers/w13095.pdf?new window=1.

Hendricks, Lutz and Schoellman Todd. "Student Abilities During the Expansion of U.S. Education, 1950-2000." Unpublished manuscript, Department of Economics, University of North Carolina-Chapel Hill, 2011; www.lhendricks.org/Research/paper abil.pdf.

Hirsch, Barry T. "Why Do Part-Time Workers Earn Less? The Role of Worker and Job Skills.” Industrial and Labor Relations Review, July 2005, 58(4), pp. 525-51.

Hirsch, Boris; König, Marion and Möller, Joachim. "Is There a Gap in the Gap? Regional Differences in the Gender Pay Gap.” IZA Discussion Paper No. 4231, Institute for the Study of Labor, June 2009; http://ftp.iza.org/dp4231.pdf.

Hotchkiss, Julie L.; Pitts, M. Melinda and Robertson, John C. "The Push-Pull Effects of the Information Technology Boom and Bust: Insight from Matched Employer-Employee Data.” Economic Development Quarterly, August 2008, 22(3), pp. 200-12.

Hotchkiss, Julie L.; Pitts, M. Melinda and Walker, Mary Beth. "Assessing the Impact of Education and Marriage on Labor Market Exit Decisions of Women.” Working Paper No 2010-2, Federal Reserve Bank of Atlanta, February 2010; www.frbatlanta.org/documents/pubs/wp/wp1002.pdf.

Ingram, Beth F. and Neumann, George R. “The Returns to Skill.” Labour Economics, February 2006, 13(1), pp. 35-59.

Jann, Ben. "The Blinder-Oaxaca Decomposition for Linear Regression Models.” Stata Journal, 2008, 8(4), pp. 453-79.

Katz , Lawrence F. and Murphy, Kevin M. "Changes in Relative Wages, 1963-1987: Supply and Demand Factors." Quarterly Journal of Economics, 1992, 107(1), pp. 35-78.

Kranz, Daniel F. "Why Has Wage Inequality Increased More in the USA than in Europe? An Empirical Investigation of the Demand and Supply of Skill." Applied Economics, April 2006, 38(7), pp. 771-88.

Krueger, Alan B. "How Computers Have Changed the Wage Structure: Evidence from Microdata: 1984-1989." Quarterly Journal of Economics, February 1993, 108(1), pp. 33-60.

Lemieux, Thomas. "Post-Secondary Education and Increasing Wage Inequality.” NBER Working Paper No. 12077, National Bureau of Economic Research, 2006; www.nber.org/papers/w12077.pdf. 
Moretti, Enrico. "Estimating the Social Return to Higher Education: Evidence from Longitudinal and Repeated Cross-Sectional Data." Journal of Econometrics, July-August 2004, 121(1-2), pp. 175-212.

Nervis, Allan. The State Universities and Democracy. Urbana, IL: University of Illinois Press, 1962.

Oehlert, Gary W. “A Note on the Delta Method.” American Statistician, February 1992, 46(1), pp. 27-9.

Phillips, Peter C.B. and Park, Joon Y. "On the Formulation of Wald Tests of Nonlinear Restrictions." Econometrica, September 1988, 56(5), pp, 1065-83.

Piketty, Thomas and Saez, Emmanuel. "Income Inequality in the United States, 1913-1998." Quarterly Journal of Economics, February 2003, 118(1), pp. 1-39.

Tolbert, Charles M. and Sizer, Molly. “U.S. Commuting Zones and Labor Market Areas: A 1990 Update.” ERS Staff Paper No. 9614, Economic Research Service, Rural Economy Division, U.S. Department of Agriculture; September 1996; www.ers.usda.gov/briefing/rurality/lmacz/LMACZ1990.pdf.

Topel, Robert H. "Factor Proportions and Relative Wages: The Supply-Side Determinants of Wage Inequality." Journal of Economic Perspectives, Spring 1997, 11(2), 55-74.

Wellington, Alison J. "Changes in the Male/Female Wage Gap, 1976-1985." Journal of Human Resources, Spring 1993, 28(2), pp. 383-411.

Wheeler, Christopher H. "Evidence on Wage Inequality, Worker Education, and Technology." Federal Reserve Bank of St. Louis Review, May/June 2005, 87(3), pp. 375-93;

http://research.stlouisfed.org/publications/review/05/05/Wheeler.pdf. 


\section{APPENDIX A}

\section{Variable Descriptions and Data Sources}

\section{Variable Descriptions and Data Sources Overview}

The data used for the analysis in this paper are from a number of sources. The primary data source is the Integrated Public Use Microdata Series (IPUMS) and was obtained from the Minnesota Population Center at the University of Minnesota. Commuting zone (CZ)-level regressors are constructed using the individual-level data in the IPUMS. In particular, average demographics and labor market characteristics are constructed based on CZs with data from the IPUMS.

Data for industry-level investment in technology are obtained from the National Income and Product Accounts (NIPA). Data for industry value added, designed to capture overall product demand-and thus worker demand - also come from NIPA.

Data for computer use at work and home and unionization by industry are obtained from the Current Population Survey (CPS). Data from the National Center for Education Statistics (NCES) are used to obtain zip codes for all institutions of higher learning, which are then mapped onto CZs. Detailed descriptions and sources of all variables used in the analysis are provided in Table A1.

\section{Table A1}

\section{Variable Descriptions and Construction and Data Sources}

Dependent variable: Individual log hourly wage. All dollar values are deflated to 2000 values using the personal consumption expenditures (PCE) chain-type price deflator. All regressors, even if CZ ( $k$ )- or industry ( $j)$-specific, are measured at the individual level (i). See the next section for information related to construction of CZs.

\begin{tabular}{|c|c|c|}
\hline Regressors & Description & Data source \\
\hline \multicolumn{3}{|c|}{ Demand factors } \\
\hline $\begin{array}{l}\text { computer }_{j} \\
\text { software }_{j}\end{array}$ & $\begin{array}{l}\text { Industry-specific (three-digit NAICS) dollar investment in high-tech } \\
\text { equipment and software; millions of dollars. Expected to capture industry } \\
\text { demand for technologically astute workers. }\end{array}$ & NIPA \\
\hline comwork $_{\mathrm{i}}$ & $\begin{array}{l}\text { Measures an individual's use of a computer at work. A reduced-form OLS } \\
\text { model is estimated using the CPS to determine a person's probability of using } \\
\text { a computer at work. The parameter estimates are then applied to the IPUMS } \\
\text { to obtain a predicted probability of an individual using a computer at work. } \\
\text { The earliest CPS survey of computer and Internet use was conducted in 1984; } \\
\text { this supplement is used as a proxy for computer use in } 1980 .\end{array}$ & $\begin{array}{l}\text { CPS Computer and } \\
\text { Internet Use } \\
\text { Supplement }\end{array}$ \\
\hline $\mathrm{VA}_{\mathrm{j}}$ & $\begin{array}{l}\text { Industry-specific value added, measured as the dollar value of output minus } \\
\text { the value of intermediate inputs. Expected to capture total derived demand } \\
\text { for workers. }\end{array}$ & NIPA \\
\hline $\begin{array}{l}\text { EmplShare }_{k j} \\
\text { EmplShare }_{k i}\end{array}$ & $\begin{array}{l}\text { Share of total workforce in CZ } k \text { that is employed in the worker's industry } j \\
\text { (occupation } i \text { ). Expected to capture local labor market demand for employment } \\
\text { across industries. }\end{array}$ & IPUMS \\
\hline \multicolumn{3}{|l|}{ Supply factors } \\
\hline comhome $_{i}$ & $\begin{array}{l}\text { Measures an individual's use of a computer at home. A reduced-form OLS } \\
\text { model is estimated using the CPS to determine a person's probability of using } \\
\text { a computer at home. The parameter estimates are then applied to the IPUMS } \\
\text { to obtain a predicted probability of an individual using a computer at home. } \\
\text { The earliest CPS survey of computer and Internet use was conducted in 1984; } \\
\text { this supplement is used as a proxy for computer use in } 1980 \text {. }\end{array}$ & $\begin{array}{l}\text { CPS Computer and } \\
\text { Internet Use } \\
\text { Supplement }\end{array}$ \\
\hline
\end{tabular}

NOTE: CPS, Current Population Survey; IPUMS, Integrated Public Use Microdata Series; NAICS, North American Industry Classification System; NCES, National Center for Education Statistics; NIPA, National Income and Product Accounts; OLS, ordinary least squares. 
Table A1, cont'd

Variable Descriptions and Construction and Data Sources

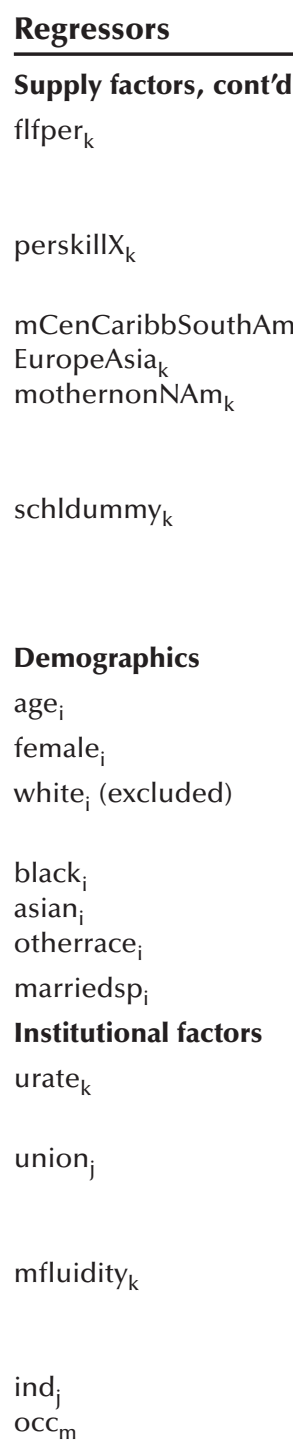

Description

Data source

This is a measure of the percent of the CZ labor force that is female. Others have concluded that female workers are lower-paid substitutes for low-skilled men, and their presence could drive down wages of low-skilled workers.

Percent of the CZ population that is of skill group X (e.g., high school only, college graduate).

Percent of CZ population born in Central America, the Caribbean, or South America; percent of CZ population born in Europe or Asia; and percent of CZ population born in other non-North American areas (e.g., African countries, Arctic regions). Immigrant shares are expected to capture the effect of immigration on local wage determination.

Dummy variable set equal to 1 if $\mathrm{CZ}$ has at least one college or university that offers a bachelor's degree. Zip codes of schools (obtained from the NCES) were mapped onto the CZ. Other work has used a dummy variable indicating the presence of a land-grant university only (see Nervis, 1962, and Moretti, 2004).

Age of individual (and its squared value).

Dummy variable set equal to 1 if individual is female.

Dummy variable set equal to 1 if white. All race variables are constructed from IPUMS variable race. May include respondents of Hispanic ethnicity.

Dummy variables set equal to 1 if black, Asian (Chinese, Japanese, or other Asian or Pacific Islander), or any other race.

Dummy variable set equal to 1 if married with a spouse present.

U.S. Department of

CZ-level unemployment rate; constructed using individual labor force data from the IPUMS. Expected to capture current local labor market conditions. Industry-specific unionization percent. Expected to measure the degree of noncompetitive wage-setting mechanisms present in worker's industry.

Percent of the CZ that lived in a different state five years ago. Expected to capture the mobility of workers in the local labor market; a greater degree of mobility makes a labor market more competitive.

Dummy variables for broad industry $(j)$ and occupation $(m)$ classifications. Expected to capture occupation- and industry-specific determinants of wages not otherwise controlled for.
IPUMS Education NCES

IPUMS

IPUMS

IPUMS

IPUMS

IPUMS

IPUMS

IPUMS

IPUMS

CPS, Annual Social and Economic Supplement IPUMS

IPUMS 


\section{Hotchkiss and Shiferaw}

\section{Method for Assigning Commuting Zones to Individuals}

Data on CZs are extracted from the IPUMS. The original data were constructed by Tolbert and Sizer (1996), who used 1990 Census data on journey-to-work county commuting flows to construct $741 \mathrm{CZs}$ (clusters of counties with strong commuting ties). We use the same (1990) definition of CZs for all analysis years (1980, 1990, and 2000) for a consistent definition of a labor market area throughout our analysis.

A CZ is assigned to an individual in the sample by matching CZs to either public use microdata (PUMA) for 1990 and 2000 or a similarly defined county group (CNTYGRP) for 1980. Because each PUMA or CNTYGRP can contain multiple CZs, we use the following method to assign each observation in a PUMA or CNTYGRP to a CZ (similar to the method used by Autor and Dorn, 2008):

(i) The CZ dataset is merged into the IPUMS dataset that contains PUMA/CNTYGRP by county federal information processing standards (FIPS) codes.

(ii) Depending on the year, between 68 and 82 percent of CZs are matched exclusively to one PUMA or CNTYGRP. In 2000, 1,677 of the 2,052 PUMAs (82\%) match to a single CZ. In 1990, 1,348 of the 1,726 PUMAs (78\%) match to a single CZ. In 1980, 788 of the 1,154 county groups (68\%) match to a single CZ.

(iii) When the match between CZ and PUMA/CNTYGRP is not exclusive, a random assignment strategy is used to distribute the PUMA/CNTYGRP population across the appropriate CZs.

(a) Population weights are created for each CZ within a PUMA or CNTYGRP. The weights are equal to the share of the PUMA or CNTYGRP population in each CZ.

(b) Each IPUMS observation within a PUMA or CNTYGRP is assigned a value from a uniform random variable distribution.

(c) Each person is then assigned a CZ based on the CZ's population share weight and the person's uniform distribution value. For example (see diagram below), if PUMA 1's population is distributed across CZ I (10 percent), CZ $m$ (30 percent), and CZ $n$ (60 percent), then individuals from PUMA 1 with a uniform draw between 0 and 0.10 will be assigned to $C Z$ l; individuals with a draw between 0.10 and 0.40 will be assigned to $\mathrm{CZ} m$; and the remaining population is assigned to $\mathrm{CZ} n$.

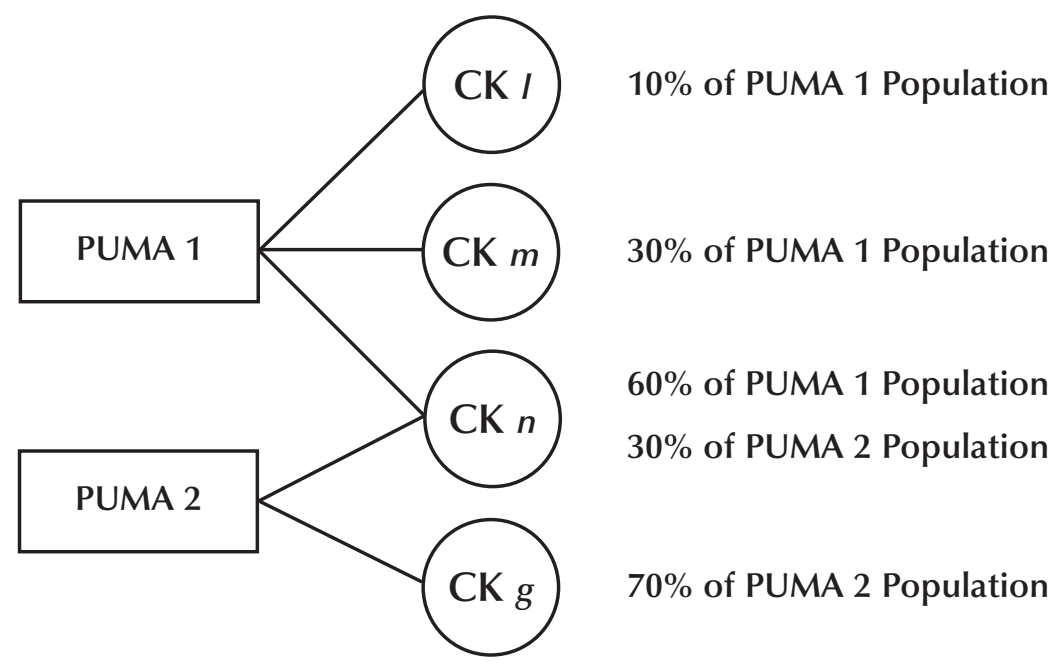




\section{APPENDIX B}

\section{OLS Parameter Estimates of Log Wage Equations by Education and Year}

\begin{tabular}{|c|c|c|c|c|c|c|}
\hline \multirow[b]{2}{*}{ Regressors } & \multicolumn{2}{|c|}{1980} & \multicolumn{2}{|c|}{1990} & \multicolumn{2}{|c|}{2000} \\
\hline & High school & College & High school & College & High school & College \\
\hline \multicolumn{7}{|l|}{ Demand factors } \\
\hline Computer investment ( $\$$ billions) & $\begin{array}{l}0.0064^{* * *} \\
(0.002)\end{array}$ & $\begin{array}{l}0.0155^{* * *} \\
(0.003)\end{array}$ & $\begin{array}{l}-0.0410^{* * *} \\
(0.001)\end{array}$ & $\begin{array}{l}-0.0521^{* * *} \\
(0.001)\end{array}$ & $\begin{array}{l}-0.0054^{* * *} \\
(0.000)\end{array}$ & $\begin{array}{l}-0.0071^{* * *} \\
(0.000)\end{array}$ \\
\hline Software investment ( $\$$ billions) & $\begin{array}{l}0.1336^{* * *} \\
(0.002)\end{array}$ & $\begin{array}{l}0.1847^{* * *} \\
(0.005)\end{array}$ & $\begin{array}{l}0.1262^{* * *} \\
(0.001)\end{array}$ & $\begin{array}{l}0.1469^{* * *} \\
(0.002)\end{array}$ & $\begin{array}{l}0.0169^{* * *} \\
(0.000)\end{array}$ & $\begin{array}{l}0.0182^{* * *} \\
(0.000)\end{array}$ \\
\hline Probability of computer use at work & $\begin{array}{l}0.5058^{* * *} \\
(0.017)\end{array}$ & $\begin{array}{l}0.2708^{* * *} \\
(0.030)\end{array}$ & $\begin{array}{l}0.5629^{* * *} \\
(0.014)\end{array}$ & $\begin{array}{l}0.6902^{* * *} \\
(0.023)\end{array}$ & $\begin{array}{l}0.2806^{* * *} \\
(0.015)\end{array}$ & $\begin{array}{l}0.9438^{* * *} \\
(0.027)\end{array}$ \\
\hline Industry value added ( $\$$ trillions) & $\begin{array}{l}0.2848^{* * *} \\
(0.010)\end{array}$ & $\begin{array}{l}0.3761^{* * *} \\
(0.019)\end{array}$ & $\begin{array}{l}0.3976^{* * *} \\
(0.006)\end{array}$ & $\begin{array}{l}0.4947^{* * *} \\
(0.009)\end{array}$ & $\begin{array}{l}0.0309^{* * *} \\
(0.005)\end{array}$ & $\begin{array}{l}0.0775^{* * *} \\
(0.006)\end{array}$ \\
\hline Industry employment share & $\begin{array}{l}0.5047^{* * *} \\
(0.017)\end{array}$ & $\begin{array}{l}0.7450^{* * *} \\
(0.040)\end{array}$ & $\begin{array}{l}0.5758^{* * *} \\
(0.017)\end{array}$ & $\begin{array}{l}0.8754^{* * *} \\
(0.035)\end{array}$ & $\begin{array}{l}0.5337^{* * *} \\
(0.018)\end{array}$ & $\begin{array}{l}0.7913^{* * *} \\
(0.033)\end{array}$ \\
\hline Occupation employment share & $\begin{array}{l}0.1071^{* * * *} \\
(0.022)\end{array}$ & $\begin{array}{l}0.5031^{* * *} \\
(0.054)\end{array}$ & $\begin{array}{l}0.0477^{* *} \\
(0.023)\end{array}$ & $\begin{array}{l}0.1705^{* * *} \\
(0.049)\end{array}$ & $\begin{array}{l}0.5281^{* * *} \\
(0.024)\end{array}$ & $\begin{array}{l}-0.5083^{* * *} \\
(0.048)\end{array}$ \\
\hline \multicolumn{7}{|l|}{ Supply factors } \\
\hline Probability of computer use at home & $\begin{array}{l}0.2569^{* * *} \\
(0.006)\end{array}$ & $\begin{array}{l}0.2889 * * * \\
(0.014)\end{array}$ & $\begin{array}{l}0.1344^{* * *} \\
(0.008)\end{array}$ & $\begin{array}{l}0.2287^{* * *} \\
(0.016)\end{array}$ & $\begin{array}{l}0.4537^{* * *} \\
(0.014)\end{array}$ & $\begin{array}{l}0.6486^{* * *} \\
(0.042)\end{array}$ \\
\hline Female share of CZ labor force & $\begin{array}{l}-0.4929 * * * \\
(0.031)\end{array}$ & $\begin{array}{l}-0.7329 * * * \\
(0.066)\end{array}$ & $\begin{array}{l}0.7022^{* * *} \\
(0.036)\end{array}$ & $\begin{array}{l}0.4925^{* * *} \\
(0.066)\end{array}$ & $\begin{array}{l}0.3309^{* * *} \\
(0.039)\end{array}$ & $\begin{array}{l}-0.3157^{* * *} \\
(0.063)\end{array}$ \\
\hline CZ population (lagged, millions) & $\begin{array}{l}2.1561^{* * * *} \\
(0.050)\end{array}$ & $\begin{array}{l}1.7968^{* * *} \\
(0.099)\end{array}$ & $\begin{array}{l}0.3476^{* * *} \\
(0.009)\end{array}$ & $\begin{array}{l}0.4070^{* * *} \\
(0.013)\end{array}$ & $\begin{array}{l}0.0097^{* * *} \\
(0.000)\end{array}$ & $\begin{array}{l}0.0105^{* * *} \\
(0.001)\end{array}$ \\
\hline Share of CZ with high school diploma (lagged) & $\begin{array}{l}0.1485^{* * *} \\
(0.009)\end{array}$ & - & $\begin{array}{l}0.1168^{* * *} \\
(0.009)\end{array}$ & - & $\begin{array}{l}-0.2650^{* * *} \\
(0.011)\end{array}$ & - \\
\hline Share of CZ with college degree (lagged) & - & $\begin{array}{l}1.5064^{* * *} \\
(0.080)\end{array}$ & - & $\begin{array}{l}0.7076^{* * *} \\
(0.051)\end{array}$ & - & $\begin{array}{l}1.1516^{* * *} \\
(0.031)\end{array}$ \\
\hline $\begin{array}{l}\text { Share of CZ born in Latin America or the } \\
\text { Caribbean (lagged) }{ }^{+}\end{array}$ & $\begin{array}{l}-1.0993^{* * *} \\
(0.038)\end{array}$ & $\begin{array}{l}-0.3310^{* * *} \\
(0.075)\end{array}$ & $\begin{array}{l}-0.6587^{* * *} \\
(0.017)\end{array}$ & $\begin{array}{l}-0.3697^{* * *} \\
(0.028)\end{array}$ & $\begin{array}{l}-0.5268^{* * *} \\
(0.013)\end{array}$ & $\begin{array}{l}-0.1895^{* * *} \\
(0.020)\end{array}$ \\
\hline Share of CZ born in Europe or Asia (lagged) & $\begin{array}{l}1.5807^{* * *} \\
(0.034)\end{array}$ & $\begin{array}{l}0.5972^{* * *} \\
(0.067)\end{array}$ & $\begin{array}{l}3.1575^{* * *} \\
(0.031)\end{array}$ & $\begin{array}{l}1.7684^{* * *} \\
(0.044)\end{array}$ & $\begin{array}{l}1.8391^{* * *} \\
(0.025)\end{array}$ & $\begin{array}{l}1.3050^{* * *} \\
(0.033)\end{array}$ \\
\hline $\begin{array}{l}\text { Share of CZ born in other non-North American } \\
\text { countries (lagged) }\end{array}$ & $\begin{array}{l}-1.5441^{* * *} \\
(0.060)\end{array}$ & $\begin{array}{c}0.0038 \\
(0.117)\end{array}$ & $\begin{array}{l}0.1026^{*} \\
(0.057)\end{array}$ & $\begin{array}{l}1.1482^{* * *} \\
(0.084)\end{array}$ & $\begin{array}{l}1.0670^{* * *} \\
(0.053)\end{array}$ & $\begin{array}{l}1.8213^{* * *} \\
(0.069)\end{array}$ \\
\hline University or college in CZ & $\begin{array}{l}0.0521^{* * *} \\
(0.003)\end{array}$ & $\begin{array}{l}0.0236^{* * *} \\
(0.009)\end{array}$ & $\begin{array}{l}0.0241^{* * *} \\
(0.002)\end{array}$ & $\begin{array}{l}0.0227^{* * *} \\
(0.005)\end{array}$ & $\begin{array}{l}0.0143^{* * *} \\
(0.002)\end{array}$ & $\begin{array}{l}0.0173^{* * *} \\
(0.005)\end{array}$ \\
\hline \multicolumn{7}{|l|}{ Demographics } \\
\hline Age & $\begin{array}{l}0.0378^{* * *} \\
(0.000)\end{array}$ & $\begin{array}{l}0.0595^{* * *} \\
(0.001)\end{array}$ & $\begin{array}{l}0.0386^{* * *} \\
(0.000)\end{array}$ & $\begin{array}{l}0.0462^{* * *} \\
(0.001)\end{array}$ & $\begin{array}{l}0.0363^{* * *} \\
(0.000)\end{array}$ & $\begin{array}{l}0.0498^{* * *} \\
(0.001)\end{array}$ \\
\hline Age squared & $\begin{array}{l}-0.0003^{* * *} \\
(0.000)\end{array}$ & $\begin{array}{l}-0.0005^{* * *} \\
(0.000)\end{array}$ & $\begin{array}{l}-0.0003^{* * *} \\
(0.000)\end{array}$ & $\begin{array}{l}-0.0004^{* * *} \\
(0.000)\end{array}$ & $\begin{array}{l}-0.0003^{* * *} \\
(0.000)\end{array}$ & $\begin{array}{l}-0.0005^{* * *} \\
(0.000)\end{array}$ \\
\hline Female & $\begin{array}{l}-0.3478^{* * *} \\
(0.002)\end{array}$ & $\begin{array}{l}-0.2489^{* * *} \\
(0.005)\end{array}$ & $\begin{array}{l}-0.3615^{* * *} \\
(0.002)\end{array}$ & $\begin{array}{l}-0.3038^{* * *} \\
(0.004)\end{array}$ & $\begin{array}{l}-0.2961^{* * *} \\
(0.002)\end{array}$ & $\begin{array}{l}-0.3064^{* * *} \\
(0.003)\end{array}$ \\
\hline
\end{tabular}

NOTE: Standard deviations are listed in parentheses. Because of the potential endogeneity, CZ population, shares of CZ with different education degrees, and immigration shares are all lagged a decade (e.g., the 1990 value is used in the 2000 regression). ${ }^{* * *}, * *$, and * indicate significance at the 99,95 , and 90 percent confidence levels, respectively. ${ }^{\dagger}$ The excluded immigration share in CZ is North

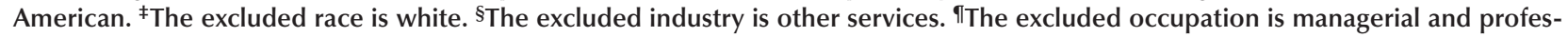
sion specialty. OLS, ordinary least squares. 


\section{APPENDIX B, cont'd}

\section{OLS Parameter Estimates of Log Wage Equations by Education and Year}

\begin{tabular}{|c|c|c|c|c|c|c|}
\hline \multirow[b]{2}{*}{ Regressors } & \multicolumn{2}{|c|}{1980} & \multicolumn{2}{|c|}{1990} & \multicolumn{2}{|c|}{2000} \\
\hline & High school & College & High school & College & High school & College \\
\hline \multicolumn{7}{|l|}{ Demographics, cont'd } \\
\hline Black $^{\ddagger}$ & $\begin{array}{l}-0.0083^{* * *} \\
(0.002)\end{array}$ & $\begin{array}{l}0.0360^{* * *} \\
(0.004)\end{array}$ & $\begin{array}{l}-0.0098^{* * *} \\
(0.002)\end{array}$ & $\begin{array}{l}0.0530^{* * *} \\
(0.004)\end{array}$ & $\begin{array}{l}0.0132^{* * *} \\
(0.002)\end{array}$ & $\begin{array}{l}0.0625^{* * *} \\
(0.004)\end{array}$ \\
\hline Asian & $\begin{array}{l}-0.0330^{* * *} \\
(0.004)\end{array}$ & $\begin{array}{l}-0.0710^{* * *} \\
(0.006)\end{array}$ & $\begin{array}{l}-0.0891^{* * *} \\
(0.004)\end{array}$ & $\begin{array}{l}-0.0546^{* * *} \\
(0.004)\end{array}$ & $\begin{array}{l}-0.0778^{* * *} \\
(0.003)\end{array}$ & $\begin{array}{l}-0.0283^{* * *} \\
(0.004)\end{array}$ \\
\hline Other race & $\begin{array}{l}-0.0122^{* *} \\
(0.005)\end{array}$ & $\begin{array}{l}-0.0559^{* * *} \\
(0.015)\end{array}$ & $\begin{array}{c}-0.0014 \\
(0.005)\end{array}$ & $\begin{array}{l}-0.0256^{* *} \\
(0.012)\end{array}$ & $\begin{array}{l}-0.0501^{* * *} \\
(0.002)\end{array}$ & $\begin{array}{l}-0.0696 * * * \\
(0.004)\end{array}$ \\
\hline Married with spouse present & $\begin{array}{l}0.0621^{* * *} \\
(0.001)\end{array}$ & $\begin{array}{l}0.0773^{* * *} \\
(0.002)\end{array}$ & $\begin{array}{l}0.0882^{* * *} \\
(0.001)\end{array}$ & $\begin{array}{l}0.1066^{* * *} \\
(0.002)\end{array}$ & $\begin{array}{l}0.1022^{* * *} \\
(0.002)\end{array}$ & $\begin{array}{l}0.0951^{* * *} \\
(0.002)\end{array}$ \\
\hline \multicolumn{7}{|l|}{ Institutional factors } \\
\hline CZ unemployment rate & $\begin{array}{l}1.6755^{* * *} \\
(0.039)\end{array}$ & $\begin{array}{l}1.9837^{* * *} \\
(0.079)\end{array}$ & $\begin{array}{l}0.4808^{* * *} \\
(0.046)\end{array}$ & $\begin{array}{l}1.6019^{* * *} \\
(0.077)\end{array}$ & $\begin{array}{l}1.2773^{* * *} \\
(0.051)\end{array}$ & $\begin{array}{l}1.4432^{* * *} \\
(0.083)\end{array}$ \\
\hline Unionization & $\begin{array}{l}0.3190^{* * *} \\
(0.005)\end{array}$ & $\begin{array}{l}0.2478^{* * *} \\
(0.011)\end{array}$ & $\begin{array}{l}0.3788^{* * *} \\
(0.005)\end{array}$ & $\begin{array}{l}0.0914^{* * *} \\
(0.009)\end{array}$ & $\begin{array}{l}0.3080^{* * *} \\
(0.005)\end{array}$ & $\begin{array}{l}-0.2073^{* * *} \\
(0.008)\end{array}$ \\
\hline Mobility rate of $\mathrm{CZ}$ population & $\begin{array}{l}0.2707^{* * *} \\
(0.010)\end{array}$ & $\begin{array}{l}0.1205^{* * *} \\
(0.022)\end{array}$ & $\begin{array}{c}-0.0130 \\
(0.010)\end{array}$ & $\begin{array}{l}-0.0836^{* * *} \\
(0.018)\end{array}$ & $\begin{array}{l}0.1233^{* * *} \\
(0.011)\end{array}$ & $\begin{array}{l}-0.2159^{* * *} \\
(0.018)\end{array}$ \\
\hline \multicolumn{7}{|l|}{ Industries $\$$} \\
\hline Natural resources and mining & $\begin{array}{l}0.2234^{* * *} \\
(0.004)\end{array}$ & $\begin{array}{l}0.3976^{* * *} \\
(0.010)\end{array}$ & $\begin{array}{l}0.2513^{* * *} \\
(0.004)\end{array}$ & $\begin{array}{l}0.4682^{* * *} \\
(0.007)\end{array}$ & $\begin{array}{l}0.1216^{* * *} \\
(0.004)\end{array}$ & $\begin{array}{l}0.3037^{* * *} \\
(0.009)\end{array}$ \\
\hline Construction & $\begin{array}{l}0.1631^{* * *} \\
(0.003)\end{array}$ & $\begin{array}{l}0.3168^{* * *} \\
(0.008)\end{array}$ & $\begin{array}{l}0.0912^{* * *} \\
(0.003)\end{array}$ & $\begin{array}{l}0.2777^{* * *} \\
(0.006)\end{array}$ & $\begin{array}{l}0.0569^{* * *} \\
(0.003)\end{array}$ & $\begin{array}{l}0.2745^{* * *} \\
(0.006)\end{array}$ \\
\hline Manufacturing & $\begin{array}{l}0.1711^{* * *} \\
(0.003)\end{array}$ & $\begin{array}{l}0.3838^{* * *} \\
(0.007)\end{array}$ & $\begin{array}{l}0.1904^{* * *} \\
(0.003)\end{array}$ & $\begin{array}{l}0.4394^{* * *} \\
(0.005)\end{array}$ & $\begin{array}{l}0.1399 * * * \\
(0.002)\end{array}$ & $\begin{array}{l}0.4362^{* * *} \\
(0.005)\end{array}$ \\
\hline Transportation and utilities & $\begin{array}{l}0.2098^{* * *} \\
(0.004)\end{array}$ & $\begin{array}{l}0.3789^{* * *} \\
(0.009)\end{array}$ & $\begin{array}{l}0.2132^{* * *} \\
(0.003)\end{array}$ & $\begin{array}{l}0.4274^{* * *} \\
(0.006)\end{array}$ & $\begin{array}{l}0.1261^{* * *} \\
(0.003)\end{array}$ & $\begin{array}{l}0.4730^{* * *} \\
(0.006)\end{array}$ \\
\hline Wholesale trade & $\begin{array}{l}0.0125^{* *} \\
(0.005)\end{array}$ & $\begin{array}{l}0.1855^{* * *} \\
(0.011)\end{array}$ & $\begin{array}{c}-0.0018 \\
(0.005)\end{array}$ & $\begin{array}{l}0.2669^{* * *} \\
(0.007)\end{array}$ & $\begin{array}{l}0.0411^{* * *} \\
(0.004)\end{array}$ & $\begin{array}{l}0.3399 * * * \\
(0.006)\end{array}$ \\
\hline Retail trade & $\begin{array}{l}-0.0577^{* * *} \\
(0.004)\end{array}$ & $\begin{array}{l}0.0473^{* * *} \\
(0.008)\end{array}$ & $\begin{array}{l}-0.1532^{* * *} \\
(0.003)\end{array}$ & $\begin{array}{l}0.0105^{*} \\
(0.006)\end{array}$ & $\begin{array}{l}-0.0473^{* * *} \\
(0.003)\end{array}$ & $\begin{array}{l}0.1941^{* * *} \\
(0.006)\end{array}$ \\
\hline Financial activities & $\begin{array}{c}-0.0062 \\
(0.004)\end{array}$ & $\begin{array}{l}0.0898^{* * *} \\
(0.009)\end{array}$ & $\begin{array}{l}-0.1528^{* * *} \\
(0.004)\end{array}$ & $\begin{array}{l}-0.0249^{* * *} \\
(0.007)\end{array}$ & $\begin{array}{l}0.1255^{* * *} \\
(0.004)\end{array}$ & $\begin{array}{l}0.3701^{* * *} \\
(0.005)\end{array}$ \\
\hline Information & $\begin{array}{l}0.2319^{* * *} \\
(0.005)\end{array}$ & $\begin{array}{l}0.2340^{* * *} \\
(0.010)\end{array}$ & $\begin{array}{l}0.0809^{* * *} \\
(0.004)\end{array}$ & $\begin{array}{l}0.2947^{* * *} \\
(0.006)\end{array}$ & $\begin{array}{l}0.0197^{* * *} \\
(0.004)\end{array}$ & $\begin{array}{l}0.2444^{* * *} \\
(0.006)\end{array}$ \\
\hline Professional and business services & $\begin{array}{l}0.1079 * * * \\
(0.003)\end{array}$ & $\begin{array}{l}0.2565^{* * *} \\
(0.007)\end{array}$ & $\begin{array}{l}-0.0607^{* * *} \\
(0.003)\end{array}$ & $\begin{array}{l}0.0331^{* * *} \\
(0.006)\end{array}$ & $\begin{array}{c}-0.0032 \\
(0.003)\end{array}$ & $\begin{array}{l}0.2176^{* * *} \\
(0.005)\end{array}$ \\
\hline Education and health services & $\begin{array}{l}0.0561^{* * *} \\
(0.003)\end{array}$ & $\begin{array}{l}0.2219^{* * *} \\
(0.007)\end{array}$ & $\begin{array}{l}0.0057^{* *} \\
(0.003)\end{array}$ & $\begin{array}{l}0.1961^{* * *} \\
(0.005)\end{array}$ & $\begin{array}{l}-0.0355^{* * *} \\
(0.003)\end{array}$ & $\begin{array}{l}0.2039^{* * *} \\
(0.005)\end{array}$ \\
\hline Leisure and hospitality & $\begin{array}{l}0.0836^{* * *} \\
(0.004)\end{array}$ & $\begin{array}{l}0.2187^{* * *} \\
(0.010)\end{array}$ & $\begin{array}{l}0.1184^{* * *} \\
(0.004)\end{array}$ & $\begin{array}{l}0.2656^{* * *} \\
(0.007)\end{array}$ & $\begin{array}{l}0.0108^{* * *} \\
(0.003)\end{array}$ & $\begin{array}{l}0.1771^{* * *} \\
(0.006)\end{array}$ \\
\hline
\end{tabular}

NOTE: Standard deviations are listed in parentheses. Because of the potential endogeneity, CZ population, shares of CZ with different education degrees, and immigration shares are all lagged a decade (e.g., the 1990 value is used in the 2000 regression). ${ }^{* *}, * *$, and $*$ indicate significance at the 99,95 , and 90 percent confidence levels, respectively. ${ }^{+}$The excluded immigration share in CZ is North American. ${ }^{\ddagger}$ The excluded race is white. ${ }^{\S}$ The excluded industry is other services. ${ }^{\text {IT }}$ The excluded occupation is managerial and profession specialty. OLS, ordinary least squares. 


\section{APPENDIX B, cont'd}

\section{OLS Parameter Estimates of Log Wage Equations by Education and Year}

\begin{tabular}{|c|c|c|c|c|c|c|}
\hline \multirow[b]{2}{*}{ Regressors } & \multicolumn{2}{|c|}{1980} & \multicolumn{2}{|c|}{1990} & \multicolumn{2}{|c|}{2000} \\
\hline & High school & College & High school & College & High school & College \\
\hline \multicolumn{7}{|l|}{ 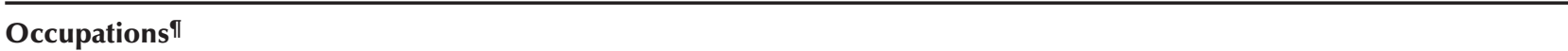 } \\
\hline Technical sales and administrative support & $\begin{array}{l}-0.1218^{* * *} \\
(0.002)\end{array}$ & $\begin{array}{l}-0.1379 * * * \\
(0.005)\end{array}$ & $\begin{array}{l}-0.1353^{* * *} \\
(0.002)\end{array}$ & $\begin{array}{l}-0.1834^{* * *} \\
(0.004)\end{array}$ & $\begin{array}{l}-0.0907^{* * *} \\
(0.002)\end{array}$ & $\begin{array}{l}-0.2108^{* * *} \\
(0.004)\end{array}$ \\
\hline Service & $\begin{array}{l}-0.2730^{* * *} \\
(0.004)\end{array}$ & $\begin{array}{l}-0.2806^{* * *} \\
(0.010)\end{array}$ & $\begin{array}{l}-0.3066^{* * *} \\
(0.004)\end{array}$ & $\begin{array}{l}-0.3621^{* * *} \\
(0.008)\end{array}$ & $\begin{array}{l}-0.2094^{* * *} \\
(0.004)\end{array}$ & $\begin{array}{l}-0.4460^{* * *} \\
(0.007)\end{array}$ \\
\hline Farming, forestry, and fishing & $\begin{array}{l}-0.4395^{* * *} \\
(0.006)\end{array}$ & $\begin{array}{l}-0.4745^{* * *} \\
(0.014)\end{array}$ & $\begin{array}{l}-0.4565^{* * *} \\
(0.004)\end{array}$ & $\begin{array}{l}-0.6334^{* * *} \\
(0.010)\end{array}$ & $\begin{array}{l}-0.3228^{* * *} \\
(0.004)\end{array}$ & $\begin{array}{l}-0.6094^{* * *} \\
(0.010)\end{array}$ \\
\hline Precision production, craft, and repair & $\begin{array}{l}-0.0820^{* * *} \\
(0.002)\end{array}$ & $\begin{array}{l}-0.1667^{* * *} \\
(0.005)\end{array}$ & $\begin{array}{l}-0.0976^{* * *} \\
(0.002)\end{array}$ & $\begin{array}{l}-0.2608^{* * *} \\
(0.004)\end{array}$ & $\begin{array}{l}-0.0784^{* * *} \\
(0.002)\end{array}$ & $\begin{array}{l}-0.3255^{* * *} \\
(0.004)\end{array}$ \\
\hline Operators, fabricators, and laborers & $\begin{array}{l}-0.1796^{* * *} \\
(0.003)\end{array}$ & $\begin{array}{l}-0.3232^{* * *} \\
(0.008)\end{array}$ & $\begin{array}{l}-0.2115^{* * *} \\
(0.003)\end{array}$ & $\begin{array}{l}-0.4465^{* * *} \\
(0.006)\end{array}$ & $\begin{array}{l}-0.1664^{* * *} \\
(0.003)\end{array}$ & $\begin{array}{l}-0.5683^{* * *} \\
(0.006)\end{array}$ \\
\hline Constant & $\begin{array}{l}0.6925^{* * *} \\
(0.024)\end{array}$ & $\begin{array}{l}-0.3260^{* * *} \\
(0.056)\end{array}$ & $\begin{array}{l}0.1315^{* * *} \\
(0.026)\end{array}$ & $\begin{array}{l}-0.6058^{* * *} \\
(0.051)\end{array}$ & $\begin{array}{c}0.0247 \\
(0.030)\end{array}$ & $\begin{array}{l}-0.1322^{* *} \\
(0.062)\end{array}$ \\
\hline Observations & $1,506,546$ & 375,090 & $1,610,134$ & 684,110 & $1,822,896$ & 922,376 \\
\hline Adjusted $R^{2}$ & 0.2530 & 0.2548 & 0.2589 & 0.2418 & 0.2043 & 0.2045 \\
\hline
\end{tabular}


